\title{
ТЕРМОДИНАМИЧЕСКИЕ СВОЙСТВА ТВЕРДЫХ РАСТВОРОВ В СИСТЕМЕ Аg-Аu-Cu
}

\author{
К.В. Чудненко, Г.А. Пальянова* \\ Институт геохимии им. А.П. Виноградова СО РАН, 664033, Иркутск, ул. Фаворского, 1а, Россия \\ * Институт геологии и минералогии им. В.С. Соболева СО РАН, \\ 630090, Новосибирск, просп. Академика Коптюга, 3, Россия
}

\begin{abstract}
Обобщены данные по содержанию меди в самородных золоте и серебре, а также серебра и золота в самородной меди. Выполнена оценка стандартных термодинамических функций твердых растворов бинарных систем $\mathrm{Au}-\mathrm{Cu}$ и $\mathrm{Ag}-\mathrm{Cu}$, а также тройной системы $\mathrm{Ag}-\mathrm{Au}-\mathrm{Cu}$. Подготовлен соответствующий модуль расчета к программному комплексу «Selektor».
\end{abstract}

Система $\mathrm{Ag}$ - $\mathrm{Au}-\mathrm{Cu}$, бинарные и тройные твердые растворы, термодинамические свойства.

\section{THERMODYNAMIC PROPERTIES OF SOLID SOLUTIONS IN THE Ag-Au-Cu SYSTEM}

\section{K.V. Chudnenko and G.A. Pal'yanova}

Data on the $\mathrm{Cu}$ content in native gold and silver and the $\mathrm{Ag}$ and $\mathrm{Au}$ contents in native copper are summarized. The standard thermodynamic functions of solid solutions the $\mathrm{Au}-\mathrm{Cu}$ and $\mathrm{Ag}-\mathrm{Cu}$ binary systems and the $\mathrm{Ag}-\mathrm{Au}-\mathrm{Cu}$ ternary system have been estimated. The corresponding calculation module is prepared for the Selektor software.

$\mathrm{Ag}-\mathrm{Au}-\mathrm{Cu}$, system binary and ternary solid solutions, thermodynamic properties

\section{ВВЕДЕНИЕ}

Медь - третий по значимости после серебра и ртути элемент-примесь, входящий в состав самородного золота [Спиридонов, 2010]. Природные соединения бинарной системы $\mathrm{Au}-\mathrm{Cu}$ обычно описывают под общим названием «медистое» золото. Помимо меди в нем часто присутствуют примеси серебра, и поэтому наиболее полно его описание может быть представлено трехкомпонентными твердыми растворами $\mathrm{Ag}-\mathrm{Au}-\mathrm{Cu}$ [Новгородова, 1983; Мурзин, Суставов, 1989]. «Медистое» золото и другие минералы системы $\mathrm{Ag}-\mathrm{Au}-\mathrm{Cu}$ интересны не только с минералогической точки зрения, но и как индикаторы возможной генетической связи золотого, серебряного и медного оруденений [Спиридонов, Плетнев, 2002; Пальянова и др., 2011, 2012; Синякова, Косяков, 2012]. Адекватность разработанных различных моделей геохимических процессов переноса и отложения элементов рудной триады $\mathrm{Ag}-\mathrm{Au}-\mathrm{Cu}$ во многом определяется надежностью термодинамической информации. Особое внимание в последние годы уделялось корректировке и оценке термодинамических свойств комплексов этих элементов в гидротермальных растворах [Sverjensky et al., 1997; Shock et al., 1997; Акинфиев, Зотов, 2010]. Однако из-за отсутствия термодинамических констант для твердых растворов системы $\mathrm{Ag}-\mathrm{Au}-\mathrm{Cu}$ при моделировании условий формирования месторождений благородных металлов присутствие примесей в составе самородных золота, серебра и меди не учитывается. Оценка термодинамических свойств кристаллических фаз бинарной системы Ag-Au и модельные расчеты с образованием самородного золота разной пробы были выполнены ранее [Пальянова и др., 2005; Пальянова, 2008]. Для проведения модельных расчетов с учетом образования твердых растворов $\mathrm{Au}-\mathrm{Cu}, \mathrm{Ag}-\mathrm{Cu}$ и $\mathrm{Ag}-\mathrm{Au}-\mathrm{Cu}$ в широком интервале $T, P$-параметров необходима оценка их термодинамических свойств. Цель данной работы - обобщить данные по содержанию меди в самородных золоте и серебре, а также серебра и золота в самородной меди и оценить термодинамические функции бинарных и тройных твердых растворов системы Ag$\mathrm{Au}-\mathrm{Cu}$. Одна из задач исследования — подготовить блок расчета к программе «Selektor-Windows» для проведения дальнейших модельных расчетов в системах, содержащих $\mathrm{Au}, \mathrm{Ag}$ и $\mathrm{Cu}$.

\section{МИНЕРАЛЫ СИСТЕМЫ Ag-Au-Cu (ОБЗОР)}

В тройной системе $\mathrm{Ag}-\mathrm{Au}-\mathrm{Cu}$ известны самородные золото, серебро и медь, а также природные твердые растворы и интерметаллиды [Разин, 1975; Новгородова, 1983; Петровская, 1993; Спиридонов, 2010]. Их химический состав соответствует кристаллическим фазам, присутствующим как в бинарных $(\mathrm{Ag}-\mathrm{Au}, \mathrm{Au}-\mathrm{Cu}$ или $\mathrm{Ag}-\mathrm{Cu})$, так и в тройной системах. 


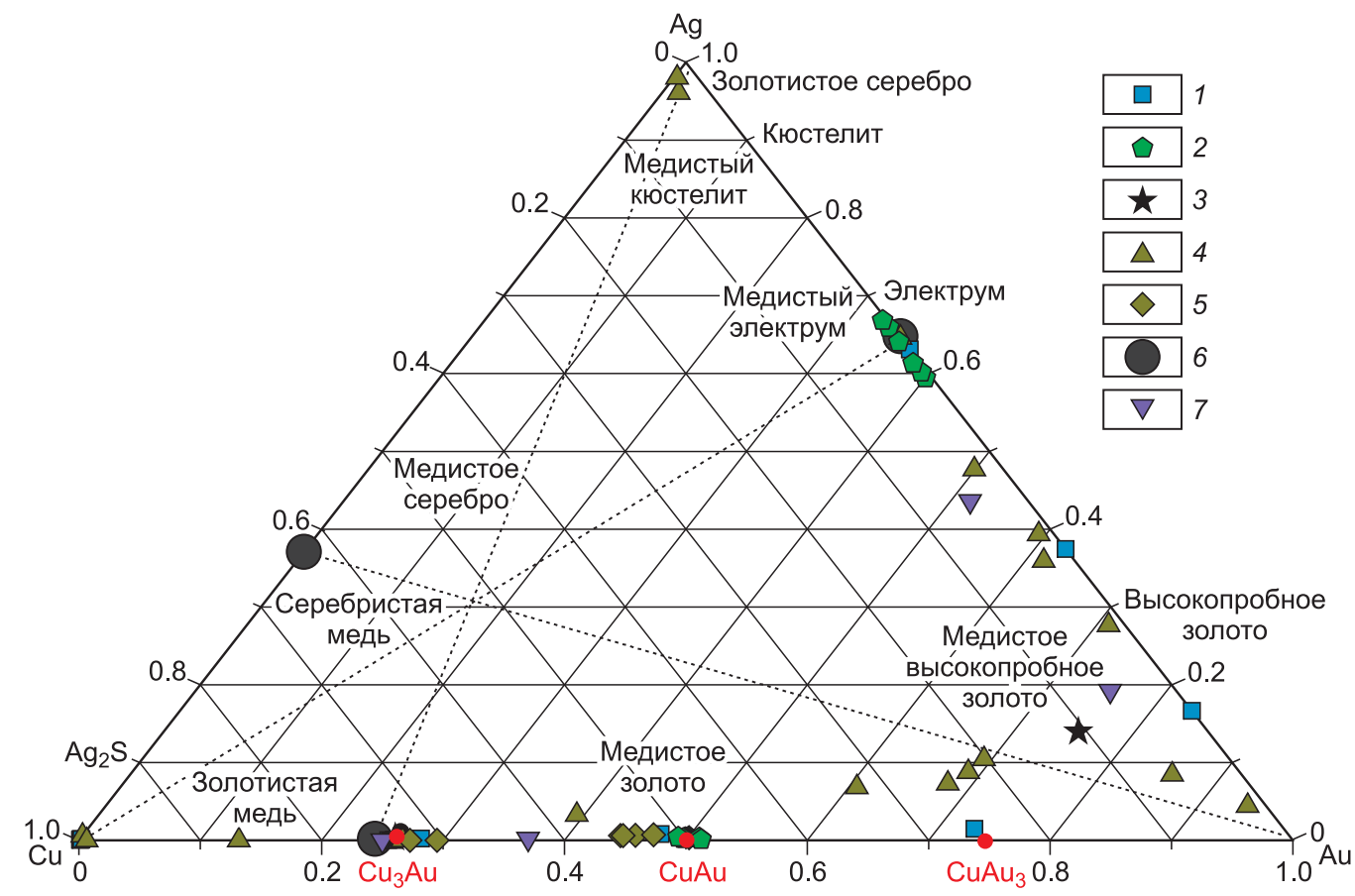

Рис. 1. Тройная диаграмма $\mathrm{Ag}$ - Au-Cu с составами (ат. доли) самородных золота и серебра, содержащих медь, а также самородной меди с примесями золота и серебра месторождения Золотая Гора и рудопроявления Мелентьевское (Южный Урал) по данным разных авторов.

Месторождение Золотая Гора: 1 - [Спиридонов, Плетнев, 2002], 2 - [Мурзин и др., 1987], 3 - [Ложечкин, 1939], 4 - [Покровский и др., 1979], 5 - [Новгородова и др., 1979], 6 - 50 мас. \% металлов; Мелентьевское рудопроявление: 7 - [Мурзин и др., 2006].

Ag-Au. Наряду с представлениями о непрерывности Ag-Au твердого раствора [Вол, Коган, 1976 - представлен обзор более 40 работ] высказываются предположения о существовании интерметаллидов состава $\mathrm{Au}_{8} \mathrm{Ag}, \mathrm{Au}_{3} \mathrm{Ag}, \mathrm{Au}_{2} \mathrm{Ag}, \mathrm{AuAg}_{3}$ и указывается на наличие прерывистости в этом ряду [Моисеенко, 1977; Петровская, Новгородова, 1980; Новгородова, 1983; Конеев, 2006]. Распад Ag-Au твердого раствора возможен в условиях крайне низких температур, недостижимых в природных условиях [Norman, Warren, 1951]. По результатам тысяч прецизионных анализов самородных золота и серебра установлено, что ряд Ag-Au непрерывен по составу [Спиридонов, 2010]. В зависимости от соотношений этих металлов для характеристики самородного золота широко используются термины, предложенные В.И. Вернадским [1914]: «высокопробное золото» - проба 1000-700\%о ( $\left.\mathrm{Au}-\mathrm{Au}_{0.56} \mathrm{Ag}_{0.44}\right)$; «электрум» - 700-250\%о $\left(\mathrm{Au}_{0.56} \mathrm{Ag}_{0.44}-\mathrm{Au}_{0.15} \mathrm{Ag}_{0.85}\right)$; «кюстелит» - 250-100\%о $\left(\mathrm{Au}_{0.15} \mathrm{Ag}_{0.85}-\mathrm{Au}_{0.06} \mathrm{Ag}_{0.94}\right)$ (рис. 1). Более детальная классификация дана Н.В. Петровской [1993]: «весьма высокопробное золото» — проба 1000-951%, «высокопробное золото» - 950-900\%, «средней пробности» — 899800 \%, «относительно низкопробное» - 799-700 \%о, «низкопробное» или высокосеребристое (электрум) - 699-400\%, «кюстелит»-399-100\%. В обеих классификациях к самородному серебру относят составы с пробой $\leq 100 \%\left(\mathrm{Au}_{0.06} \mathrm{Ag}_{0.94}-\mathrm{Ag}\right)$.

$\mathrm{Au}-\mathrm{Cu}$. В бинарной системе $\mathrm{Au}-\mathrm{Cu}$ наряду с твердыми растворами установлены и интерметаллиды. К ним относят: $\mathrm{Cu}_{3} \mathrm{Au}$ - аурикуприд (тетрагональный и кубический), $\mathrm{CuAu}$ - купроаурид (кубический), тетрааурикуприд (тетрагональный), рожковит (ромбический), $\mathrm{CuAu}$ - кубическая фаза (название не утверждено) [Спиридонов, Плетнев, 2002]. По данным ряда авторов [Новгородова и др., 1977; Мурзин, Малюгин, 1983; Спиридонов, 2010], медистое золото часто представляет тонкую смесь фаз, состав которых близок к $\mathrm{Cu}_{3} \mathrm{Au}$ и $\mathrm{CuAu}$ или $\mathrm{CuAu}$ и $\mathrm{CuAu}_{3}$. Структуры распада самородного золота $\mathrm{c}$ повышенным содержанием меди отмечаются на многих объектах. Например, на месторождениях Моихук Бушвельдского плутона и Инсизвы (Южная Африка) самородное золото содержит тонкий скелет пластинок $\|$ (100), имеющих состав $\mathrm{Cu}_{3} \mathrm{Au}$ [Рамдор, 1962].

$\mathbf{A g}$ - Cu. На некоторых колчеданно-полиметаллических месторождениях Алтая и Узбекистана, а также в эпитермальных Ag-Au месторождениях востока России примеси меди в самородном серебре не превышают 1-2 мас. \% [Новгородова, 1983]. Для Дальнереченского района Сихотэ-Алиня характерно 
самородное серебро с примесями меди ( $\sim 5$ мас. \%) и других элементов - $\left(\mathrm{Ag}_{0.90} \mathrm{Cu}_{0.07} \mathrm{Rh}_{0.02} \mathrm{Te}_{0.01}\right)$, $\left(\mathrm{Ag}_{0.90} \mathrm{Cu}_{0.08} \mathrm{Zn}_{0.02}\right)$ [Казаченко и др., 2008]. Примеси серебра в самородной меди достигают 8-10 мас. \% [Годовиков, 1975; Новгородова, 1983].

$\mathbf{A g - A u - C u . ~ О б з о р ы , ~ к а с а ю щ и е с я ~ д е т а л ь н о г о ~ а н а л и з а ~ х и м и ч е с к о г о ~ с о с т а в а ~ м и н е р а л о в ~ т р и а д ы ~}$ Ag-Au-Cu на разных объектах, представлены в работах [Вернадский, 1914; Рамдор, 1962; Новгородова, Цепин, 1976; Самусиков, 1981; Новгородова, 1983; Петровская, 1993; Knipe, Fleet, 1997; Knight, Leitch, 2001; Спиридонов, Плетнев, 2002]. За последующие годы появилось много данных по составам самородных золота, серебра и меди на разных объектах [Bonev et al., 2002; Arif, Baker, 2004; Мурзин и др., 2006, 2007; Казаченко и др., 2008; Chapman et al., 2009; и др.]. Наиболее изучено в этом плане месторождение Золотая Гора в родингитах (Карабашский массив, Южный Урал). На тройной диаграмме $\mathrm{Ag}-$ $\mathrm{Au}-\mathrm{Cu}$ (см. рис. 1) представлены составы самородных золота и серебра, содержащих медь (в атомных долях или атомных \% / 100), а также самородной меди с примесями золота и серебра этого объекта по данным разных авторов [Ложечкин, 1939; Новгородова и др., 1977; Покровский и др., 1979; Мурзин и др., 1987; Спиридонов, Плетнев, 2002]. М.П. Ложечкиным [1939] было показано, что медистое золото обладает фазовой неоднородностью и представляет пластинчатые срастания медистого золота и электрума, образующиеся в результате распада $\mathrm{Au}-\mathrm{Cu}-\mathrm{Ag}$ твердого раствора. В.В. Мурзин с соавторами [1987] определили, что состав медистого золота представлен фазой $\mathrm{AuCu}$, а электрум характеризуется пробой 470 - 610 \%. По данным [Покровский и др., 1979], на месторождении Золотая Гора содержание серебра в $\mathrm{Au}-\mathrm{Cu}$ твердых растворах и меди в $\mathrm{Ag}-\mathrm{Au}$ твердых растворах в основном не превышают 3 мас. \%. Э.М. Спиридонов и П.А. Плетнев [2002] детально исследовали составы минералов системы $\mathrm{Au}-\mathrm{Cu}$ на месторождении Золотая Гора - это аурикуприд $\left(\mathrm{Cu}_{3} \mathrm{Au}\right)$, купроаурид $(\mathrm{AuCu})$, минерал $\mathrm{CuAu}_{3}$, а также самородная медь с примесями серебра (до 0.18 мас. \%) и золота (до 0.56 мас. \%). Аурикуприд по составу близок к стехиометрическому $\mathrm{Au}_{0.98-1.04} \mathrm{Cu}_{3.02-2.96}$ и содержит микропримеси серебра до 0.15 мас. \%. Для купроаурида установлены незначительные вариации состава $\mathrm{Cu}_{1.04-0.99} \mathrm{Au}_{0.96-1.01}$. Примеси серебра в нем меньше 0.5 мас. \% и редко достигают 1.4 мас. \%. Минерал $\mathrm{CuAu}_{3}$ обычно слагает каймы обрастания и замещения на аурикуприде и купроауриде. Его состав широко варьирует $\mathrm{Cu}_{0.99-1.24} \mathrm{Au}_{2.70-2.96} \mathrm{Ag}_{0.03-0.07}$ (ртуть присутствует в количествах до 0.6 мас. \%). По данным М.И. Новгородовой с соавторами [1977], аурикуприд содержит избыток золота (0.02-0.06 ат. доли), а $\mathrm{CuAu}$ - избыток меди $(0.07-0.12$ ат. доли). На Мелентьевском золото-полиметаллическом месторождении (Южный Урал, Россия) в родингитах, приуроченных к небольшим телам ультрабазитов, самородное золото представлено медистой и серебристой его разновидностями [Мурзин и др., 2006]. Медистое золото характеризуется составом тетрааурикуприда $\mathrm{AuCu}$ (до $0.2 \mathrm{Mac.} \% \mathrm{Ag}$ ) или реже аурикуприда $\mathrm{AuCu}_{3}$. Серебристое золото имеет пробность 670 - $860 \%$ (т.е. электрум и высокопробное золото) и содержит примеси меди (до 2 мас. \%) и ртути (до 1.2 мас. \%) (см. рис. 1).

На рис. 2 показаны составы минералов триады $\mathrm{Ag}-\mathrm{Au}-\mathrm{Cu}$, обнаруженных на других объектах [Разин, Бегизов, 1973; Oen, Kieft, 1974; Куличихина, Губанов, 1975; Knight, Leitch, 2001; Некрасов и др., 2001; Bonev et al., 2002; Кудрявцева, Кудрявцев, 2003; Arif, Baker, 2004; Дамдинов, 2004; Викентьева, Тюкова, 2007; Жмодик и др., 2008; Казаченко и др., 2008; Чекрыжов и др., 2011; Кужугет и др., 2012]. В акцессорных количествах $\mathrm{Ag}-\mathrm{Au}-\mathrm{Cu}$ сплавы широко развиты в разнообразных базит-гипербазитовых комплексах. Например, известно проявление видимого медистого золота в пределах Агардагского массива альпинотипных гипербазитов (Южная Тува, Россия) [Кудрявцева, Кудрявцев, 2003]. Наряду с медистым золотом, которое представлено фазой $\mathrm{AuCu}$, присутствует золотистое серебро (470-420 \%о) с небольшими примесями меди $(0.14-0.34$ мас. \%) и ртути (< 1.6 мас. \%). Медистое золото до 10.2 мас. \% $\mathrm{Cu}$ и от 4.0 до 17.6 мас. \% Ag установлено в благороднометалльной минерализации в базит-гипербазитах Хурай-Жалгинского массива (Восточные Саяны) [Жмодик и др., 2008]. На месторождении Зеленое (Восточные Саяны) в самородном золоте концентрации меди варьируют от следовых количеств до 2.1 мас. \%, а серебра - от 7.2 до 28.7 мас. \% [Жмодик и др., 2008]. Медистое золото с содержанием меди до 10.2 мас. \% и серебра от 14.6 до 24.6 мас. \% установлено в углеродизированных гипербазитах Оспинско-Китойского массива Восточно-Саянского пояса [Дамдинов, 2004].

Самородное золото из $\mathrm{Au-носных} \mathrm{родингитов} \mathrm{и} \mathrm{зон} \mathrm{оталькования} \mathrm{среди} \mathrm{серпентинитов} \mathrm{с} \mathrm{россыпи}$ Уитон Грик и рудопроявления «15 Миль» (Британская Колумбия, Канада) представлено медистым золотом с примесями серебра до 1.4 мас. \% и серебристым золотом, содержащим медь до 4.2 мас. \% [Knight, Leitch, 2001]. Для самородного золота этих двух объектов характерны различные текстуры, в том числе эксгаляционные.

В сульфидных рудах Талнахского и Октябрьского месторождений установлены самородное золото и серебро с примесями меди (0.1-0.9 мас. \%), а также купроаурид, твердые растворы состава $\mathrm{Au}_{3} \mathrm{CuAg}$ [Разин, Бегизов, 1973]. Обычно эти минералы $\mathrm{Au}, \mathrm{Ag}$ и Сu находятся в виде мономинеральных выделений или полиминеральных сростков в ассоциации с минералами палладия и платины, сульфидами меди и железа. 


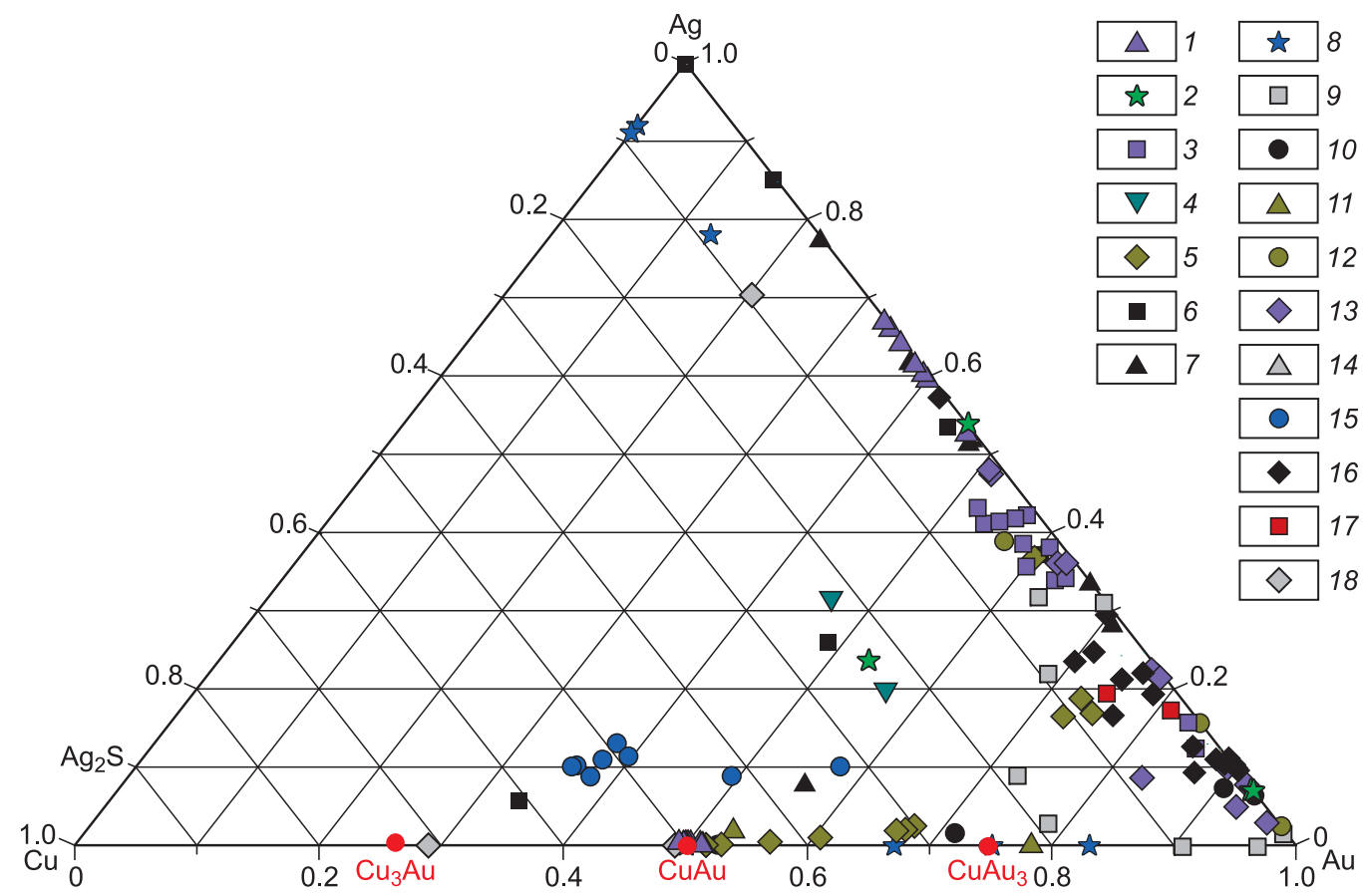

Рис. 2. Тройная диаграмма Ag-Au-Сu с составами (ат. доли) самородных золота и серебра, содержащих медь, разных объектов.

1 - гипербазиты Агардагского массива (Южная Тува, Россия) [Кудрявцева, Кудрявцев, 2003]; 2 - базит-гипербазиты ХурайЖалгинского массива (Восточные Саяны) [Жмодик и др., 2008]; 3 - месторождение Зеленое (Восточные Саяны) [Жмодик и др., 2008]; 4 - гипербазиты Оспинско-Китойского массива [Дамдинов, 2004]; 5 — россыпь Уитон Крик и рудопроявления «15 Миль» (Канада) [Knight, Leitch, 2001]; 6, 7 - Талнахское и Октябрьское месторождения [Разин, Бегизов, 1973]; 8 - рудопроявления Сихотэ-Алиня [Казаченко и др., 2008]; 9 - рудопроявление Березовое [Чекрыжов и др., 2011]; 10,11 - Хаак-Саирское и СарыгДашское рудопроявления [Кужугет и др., 2012]; 12 - россыпь Кондерского щелочно-ультраосновного массива [Некрасов и др., 2001]; 13 - Au-Cu-порфировое месторождение Бату Хиджау (Индонезия) [Arif, Baker, 2004]; 14 — месторождение Керр-Эдиссон (Канада) [Knipe, Fleet, 1997]; 15 - месторождение Бени-Буазера (Марокко) [Oen, Kieft, 1974]; 16 - Березовское месторождение [Викентьева, Тюкова, 2007]; 17 - Челопеч (Болгария) [Bonev et al., 2002]; 18 - Южно-Янгиканское месторождение (Узбекистан) [Куличихина, Губанов, 1975].

Интерметаллиды состава $\mathrm{Au}_{5} \mathrm{Cu}, \mathrm{Au}_{3} \mathrm{Cu}, \mathrm{Au}_{2} \mathrm{Cu}$ и твердые растворы $\mathrm{AuCu}-\mathrm{Au}_{2} \mathrm{Cu}$ и самородное серебро $\mathrm{Ag}_{0.78} \mathrm{Au}_{0.13} \mathrm{Cu}_{0.09}$ установлены в амфибол-пироксеновых породах Мокрушинской площади Ольгинского района и марганцевых породах Дальнегорского района Сихотэ-Алиня [Казаченко и др., 2008].

На золото-медно-порфировом месторождении Бату Хиджау (Индонезия) самородное золото содержит медь в среднем 3.1 мас. \% и серебра до 8 мас. \% в борнит-дигените и борните, а в халькопирите оно содержит меньше меди - в среднем 1.9 мас. \% и больше серебра до 21 мас. \% [Arif, Baker, 2004]. На месторождении Керр-Эдиссон (Канада) [Knipe, Fleet, 1997] установлено самородное золото с небольшими примесями меди (0.8 мас. \%) и серебра (4.2 мас. \%), а также медистое золото разного состава $\mathrm{CuAu}$ и $\mathrm{CuAu}_{3}$. В гидротермальном арсенидном $\mathrm{Ni}-\mathrm{Co}$ месторождении Бени-Буазера (Марокко) в хромититах среди серпентинизированных перидотитов в медистом золоте установлены примеси меди 11 мас. \% [Oen, Kieft, 1974], что соответствует соединению $\mathrm{CuAu}_{2.6}$.

В самородном золоте мезотермального Березовского месторождения (Урал) от ранней к поздней стадии увеличивается концентрация серебра от $1.4-14$ мас. \% до 9.3-26.7, меди - от $0.02-0.26$ до 0.05-1.83 мас. \% [Викентьева, Тюкова, 2007].

Самородное золото в ассоциации с пиритом, халькопиритом, борнитом, энаргитом, люцонитом и теннантитом высокосульфидного эпитермального $\mathrm{Au}-\mathrm{Cu}$ месторождения Челопеч (Болгария) характеризуется высокой пробой (900-1000\%), примесями серебра - до 5.27, меди - до 2.96 и $\mathrm{Fe}$ - до 0.61 мас. \% [Bonev et al., 2002]. Количество серебра в самородном золоте возрастает от Cu-Ag стадии к полиметаллической, достигая 33.87 мас. \% серебра, при этом количество меди и железа уменьшается $<0.62$ и $<0.28$ мас. $\%$ соответственно.

Медистое золото состава (мас. \%) - Au 77.0, Cu 21.2, Ag 1.4 - установлено в скарноворудном редкометалльном Южно-Янгиканском месторождении (Узбекистан) [Куличихина, Губанов, 1975]. При- 
родные микрочастицы $\mathrm{Ag}-\mathrm{Au}-\mathrm{Cu}$ сплава размером от 500 нм до 3 мкм и нестабильным составом (содержание Аu варьирует в интервале 78.65-60.65 мас. \%, $\mathrm{Cu}-14.20-29.48, \mathrm{Ag}-7.20-11.80$ ) установлены в цеолитовом проявлении Березовое, расположенном в пределах Ванчинской впадины (Приморский край) [Чекрыжов и др., 2011].

В кварцевых жилах Хаак-Саирского рудопроявления встречается золото зонального строения и разного состава (мас. \%) [Кужугет и др., 2012]: 1) золото (Au 75.55-87.83; Ag 11.02-22); 2) Сu-содержащее золото ( $\mathrm{Au} 77.99-99.87 ; \mathrm{Ag}$ 0.02—19.84; $\mathrm{Cu} 0$ - 1.08). Содержание Аu от центра зерна к краю закономерно уменьшается - до 12 мас. \%, иногда от 90.35 до 56.26 мас. \%, а содержание $\mathrm{Ag} \mathrm{и} \mathrm{Cu}$, наоборот, увеличивается.

Золото из россыпи Кондерского щелочно-ультраосновного массива представлено медистым золотом (6.9-25.0 мас. \% $\mathrm{Cu}$; единичное - 44.3 мас. \% $\mathrm{Cu}$ ) - $\mathrm{Au}_{3} \mathrm{Cu}$ (купроауридом), $\mathrm{AuCu}$ (тетрааурикупридом) и $\mathrm{AuCu}_{3}$ (аурикупридом - редко), а также серебросодержащими твердыми растворами (до 62.7 мас. \% Ag и 4.8 мас. \% Сu) [Некрасов и др., 2001]. Медистое золото, находящееся в срастании с самородным золотом без меди $\left(\mathrm{Au}_{0.83-1} \mathrm{Ag}_{0.17-0}\right)$ в аллювиальных образцах с о. Суматра, содержит примеси серебра и характеризуется составом $\mathrm{Au}_{0.14} \mathrm{Cu}_{0.79} \mathrm{Ag}_{0.06}$ и $\mathrm{Au}_{0.52} \mathrm{Cu}_{0.48} \mathrm{Ag}_{0.1}$ [Knight, Leitch, 2001].

Для многих месторождений концентрации меди в самородном золоте составляют не более 1 мас. \%. В составе самородного золота эпитермальных месторождений Узбекистана (Кызылалма, Арабулак, Кочбулак, Кайрагач, Каульды) [Конеев, 2006] количество примеси меди варьирует в интервале 0.010.83 мас. \%. На месторождении Кызылалма (Узбекистан) [Конеев, 2006] самородное серебро содержит примеси меди от 0.03 до 0.30 мас. \% и золота от 0.30 до 1.83 мас. \%. Примеси меди до 0.5 мас. \% установлены в высокопробном золоте (содержание серебра 3-11 мас. \%) Синюхинского месторождения (Алтай) [Нестеренко и др., 1980].

Таким образом, приведенные данные свидетельствуют о том, что в $\mathrm{Au}-\mathrm{Cu}$ твердых растворах содержание серебра в основном не превышает 0.10 ат. долей, а в $\mathrm{Ag-Cu}$ твердых растворах количество меди меньше 0.04 ат. долей. Результаты исследования ювелирных $\mathrm{Ag}-\mathrm{Au}-\mathrm{Cu}$ сплавов пробой 583 \% (14 карат) и $416 \%$ (10 карат) [McDonald, Sistare, 1978] также показали, что количество меди в гомогенных твердых Ag-Au растворах и содержание $\mathrm{Ag}$ в $\mathrm{Au}-\mathrm{Cu}$ растворах не превышают 4 мас. \%, что составляет не более 0.10 ат. долей $\mathrm{Cu}$ и 0.04 ат. долей $\mathrm{Ag}$ соответственно. При более высоких содержаниях $\mathrm{Ag}$ и $\mathrm{Cu}$ возможно существование метастабильных твердых $\mathrm{Ag}-\mathrm{Au}-\mathrm{Cu}$ растворов. Эти данные хорошо согласуются с результатами для природного медистого и серебристого золота. Некоторые точки, лежащие за пределами этих областей, по-видимому, представляют тонкие срастания двух фаз и являются продуктами распада твердых растворов.

$\mathrm{B}$ нашей работе мы ограничимся оценкой термодинамических функций $\mathrm{Ag}-\mathrm{Cu}, \mathrm{Au}-\mathrm{Cu}$ и $\mathrm{Ag}-\mathrm{Au}-\mathrm{Cu}$ твердых растворов, характерных для природных систем и синтетических сплавов.

Для характеристики состава твердых растворов этой рудной триады мы предлагаем использовать следующие условные названия: «медистое высокопробное золото» - составы $\mathrm{Au}_{1-0.88} \mathrm{Cu}_{0.00 n-0.12}-\mathrm{Au}_{0.56-0.44}$ $\mathrm{Ag}_{0.44-0.32} \mathrm{Cu}_{0.00 n-0.12}$, «медистый электрум» - $\mathrm{Au}_{0.56-0.44} \mathrm{Ag}_{0.44-0.32} \mathrm{Cu}_{0.00 n-0.12}-\mathrm{Au}_{0.15-0.03} \mathrm{Ag}_{0.85-0.20} \mathrm{Cu}_{0.00 n-0.12}$, «медистый кюстелит» - $\mathrm{Au}_{0.15-0.03} \mathrm{Ag}_{0.85-0.20} \mathrm{Cu}_{0.00 n-0.12}-\mathrm{Au}_{0.03-0} \mathrm{Ag}_{1-0.12} \mathrm{Cu}_{0-0.12}$. Поскольку для систем $\mathrm{Ag}-\mathrm{Cu}$ и $\mathrm{Au}-\mathrm{Cu}$ характерен ограниченный ряд составов, то логично самородное серебро, содержащее медь, называть «медистым серебром» $\left(\mathrm{Ag}-\mathrm{Ag}_{0.859} \mathrm{Cu}_{0.141}\right)$, самородную медь с примесями серебра «серебристой медью» $\left(\mathrm{Cu}-\mathrm{Ag}_{0.049} \mathrm{Cu}_{0.951}\right)$, с примесями золота - «золотистой медью» $\left(\mathrm{Cu}-\mathrm{Au}_{0.25} \mathrm{Cu}_{0.75}\right.$ $\left.\left(\mathrm{Cu}_{3} \mathrm{Au}\right)\right)$, а самородное золото с примесями меди $\mathrm{Au}_{0.75} \mathrm{Cu}_{0.25}$ - $\mathrm{Au}$ «медистое золото» (см. рис. 1).

\section{ТЕРМОДИНАМИЧЕСКИЕ СВОЙСТВА БИНАРНЫХ ТВЕРДЫХ РАСТВОРОВ В СИСТЕМЕ $\mathrm{Ag}-\mathrm{Au}-\mathrm{Cu}$}

Современная термодинамика трактует способность соединений образовывать твердые растворы с общих позиций минимума свободной энергии [Хисина, Урусов, 1987]. Использование программных средств, ориентированных на моделирование геохимических процессов и основанных на принципе минимизации энергии Гиббса, в данном контексте представляется весьма продуктивным. Развиваемый авторами программный комплекс «Селектор» [Чудненко, 2010] принадлежит к программам подобного класса и имеет вполне определенный набор термодинамических характеристик индивидуальных веществ, представленных во встроенных базах данных: значение стандартных термодинамических функций $\left(\Delta_{f} G^{0}, \Delta_{f} H^{0}, S^{0}, V^{0}\right)$ и коэффициенты уравнения теплоемкости $C_{p}$, используемые при расчете величин $G_{T}, H_{T}$ и $S_{T}$ в условиях, отличных от стандартных.

Термодинамические свойства бинарных твердых растворов в системе $\mathrm{Ag}-\mathrm{Au}-\mathrm{Cu}$ изучались во многих экспериментальных работах и расчетных моделях, в которых приводятся термодинамические характеристики либо при фиксированных значениях температуры [Hultgren et al., 1963], либо изменения избыточных термодинамических функций $\left(G^{e x}, S^{e x}\right)$ и активностей металлов в определенных интервалах 
температур [Okamoto et al., 1987; Sundman et al., 1998; Predel, 2005]. Вместе с тем отсутствует систематическая сводка термодинамических параметров конкретных твердых растворов в формате баз термодинамических данных, что делает невозможным их включение в физико-химическую модель в качестве потенциально возможных фаз при расчете равновесных минеральных ассоциаций в заданных $T, P$-условиях для проведения термодинамического моделирования формирования $\mathrm{Au}-\mathrm{pyдных,} \mathrm{Au}-\mathrm{Ag}, \mathrm{Au}-\mathrm{Cu}-п о р-$ фировых и других месторождений со значимыми содержаниями меди.

В данной работе приводятся результаты расчета стандартных термодинамических свойств (энергии Гиббса, энтропии, энтальпии) и коэффициентов уравнения зависимости теплоемкости $C_{p}$ от температуры, позволяющего производить определение значения основных термодинамических параметров в зависимости от заданной температуры $T$.

Энергия Гиббса одного моля бинарного твердого раствора $x_{1}-x_{2}$ при давлении 1 бар и температуре $T$ рассчитывалась по уравнению:

$$
G_{T}^{0}\left(x_{1}, x_{2}\right)=G^{i d}+x_{1} G_{1}^{0}+x_{2} G_{2}^{0}+G^{e x},
$$

где $x_{1}, x_{2}$ - атомные доли компонентов в растворе, $x_{2}=1-x_{1} ; G_{T}^{0}\left(x_{1}, x_{2}\right)$ - стандартная свободная энергия Гиббса твердого раствора $x_{1}-x_{2} ; G^{i d}$ - идеальная энергия смешения, равная $R T\left(x_{1} \ln x_{1}+x_{2} \ln x_{2}\right)$; $G^{e x}$ - избыточная энергия смешения Гиббса равна $x_{1} G_{1}^{e x}+x_{2} G_{2}^{e x}, G_{1}^{e x}, G_{2}^{e x}$ - избыточные парциальные энергии Гиббса компонентов раствора; $G_{1}^{0} u G_{2}^{0}$ - энергии Гиббса металлов в стандартных условиях [Robie, Hemingway, 1995].

Избыточная энергия смешения Гиббса определялась на основе использования формализма метода Редлиха-Кистера [Redlich, Kister, 1948]:

$$
G^{e x}=x_{1} x_{2} \sum_{k=0}^{n}{ }^{k} L\left(x_{1}-x_{2}\right)^{k},
$$

где ${ }^{k} L$ - параметры аппроксимирующего полинома. В выполненном исследовании авторы использовали двухчленный алгоритм Редлиха-Кистера, ограничившись двумя первыми членами многочлена (2):

$$
G^{e x}=x_{1} x_{2}\left({ }^{0} L+{ }^{1} L\left(x_{1}-x_{2}\right)\right),
$$

где ${ }^{0} L$ - параметр регулярного раствора, ${ }^{1} L$ - параметр субрегулярного раствора [Hillert, 2008]. Избыточные парциальные энергии Гиббса рассчитывались по уравнениям [Hillert, 2008]:

$$
\begin{aligned}
& G_{1}^{e x}=x_{2}^{2}\left({ }^{0} L+{ }^{1} L\left(3 x_{1}-x_{2}\right)\right), \\
& G_{2}^{e x}=x_{1}^{2}\left({ }^{0} L+{ }^{1} L\left(x_{1}-3 x_{2}\right)\right) .
\end{aligned}
$$

Активности компонентов твердого раствора соответственно вычислялись как [Hillert, 2008]:

$$
\begin{aligned}
& a_{1}=x_{1} \exp \left(G_{1}^{e x} /(R T)\right), \\
& a_{2}=x_{2} \exp \left(G_{2}^{e x} /(R T)\right) .
\end{aligned}
$$

Температурная зависимость теплоемкости может быть описана уравнением [Чудненко, 2010]:

$$
C_{P}=a+b T+c T^{-2}+d T^{2}+e T^{-3}+f T^{3}+g T^{-0.5}+h T^{-1}+i \ln (T) .
$$

Как показано в [Пальянова, 2008], для Ag-Au твердых растворов достаточно хорошее приближение может быть получено с привлечением пяти коэффициентов этого уравнения: $a, b, c, d$ и $g$. Согласно предложенной методике [Пальянова, 2008], коэффициенты полинома (3) оценивались путем аппроксимации температурной зависимости свободной энергии Гиббса, представленной в виде

$$
G_{T}=G_{T_{0}}^{0}-S_{T_{0}}^{0}\left(T-T_{0}\right)+\int_{T_{0}}^{T} C_{P} d T-T \int_{T_{0}}^{T} \frac{C_{P}}{T} d T,
$$

где $T_{0}$ — отсчетная температура $(298.15 \mathrm{~K})$.

Стандартные энтропии бинарных твердых растворов были рассчитаны по уравнению:

$$
S_{T}^{0}=S^{e x}+x_{1} S_{1}^{0}+x_{2} S_{2}^{0}+S^{i d},
$$

где $S^{e x}$ - избыточная энтропия смешения; $S_{1}^{0}, S_{2}^{0}$ - стандартные энтропии компонентов [Robie, Hemingway, 1995]; $S^{\text {id }}$ - энтропия идеального смешения, равная $-R\left(x_{1} \ln x_{1}+x_{2} \ln x_{2}\right)$. Избыточная энтропия твердого раствора оценивалась по уравнению [Anderson, 2005]: 


$$
S^{e x}=-\left(\frac{\partial G^{e x}}{\partial T}\right)_{P} .
$$

Мольный объем твердых растворов для стандартных условий был рассчитан по правилу Ретгерса на основе мольных объемов чистых металлов $V_{1}$ и $V_{2}$ [Robie, Hemingway, 1995]:

$$
V=x_{1} V_{1}+x_{2} V_{2} \text {. }
$$

Бинарная система $\mathbf{A g}-\mathbf{C u}$. Система $\mathrm{Ag}$ - $\mathrm{Cu}$ относится к системам эвтектического типа с ограниченной растворимостью компонентов друг в друге. Максимальная растворимость Сu в (Ag) paвна 14.1 мас. \%, максимальная растворимость $\mathrm{Ag}$ в $(\mathrm{Cu})-4.9$ мас. \% [Диаграммы..., 1996].

Коэффициенты уравнения (3) представлены в табл. 1. Расчет избыточной энергии твердого раствоpa $\mathrm{Ag-Cu}$ по уравнению (3) с параметрами ${ }^{0} L$ и ${ }^{1} L$ из [He et al., 2006] и [Dinsdale et al., 2008] показал хорошую согласованность с экспериментальными данными [Hultgren, 1963] (рис. 3).

Активности $\mathrm{Ag}$ и $\mathrm{Cu}$ в твердом растворе рассчитывались по известным соотношениям [Hillert, 2008] с определением избыточных энергий по уравнениям (4), (5):

$$
\begin{aligned}
& a_{\mathrm{Ag}}=x_{\mathrm{Ag}} \exp \left(G_{\mathrm{Ag}}^{e x} /(R T)\right), \\
& a_{\mathrm{Cu}}=x_{\mathrm{Cu}} \exp \left(G_{\mathrm{Cu}}^{e x} /(R T)\right) .
\end{aligned}
$$

Сопоставление расчетных активностей с данными [Hultgren, 1963] показано на рис. 4. Предварительные расчеты показали, что в целом наборы параметров уравнения Редлиха-Кистера [He et al., 2006] и [Dinsdale et al., 2008] дают результаты, близкие к экспериментальным данным (табл. 2). Для нахождения термодинамических свойств твердых растворов в системе $\mathrm{Ag}-\mathrm{Cu}$ (табл. 3) нами выбраны параметры, предложенные в модели [Dinsdale et al., 2008], имеющей несколько лучший показатель по рассчитанным значениям коэффициентов корреляции. В табл. 3 также представлены по каждому твердому раствору максимальные температуры, до которых правомочно использование приведенных параметров.

Бинарная система Ag-Au. На основании уравнений расчета термодинамических свойств $\mathrm{Ag}-\mathrm{Au}$ твердого раствора [White et al., 1957], параметры Редлиха-Кистера имеют вид (Дж/моль):

$$
\begin{gathered}
{ }^{0} L=-18618.8+5.753 T, \\
{ }^{1} L=1673.6 .
\end{gathered}
$$

Термодинамические характеристики системы $\mathrm{Ag}$ - $\mathrm{Au}$ в настоящей работе не вычислялись, их расчет проведен ранее [Пальянова, 2008]. Описание системы $\mathrm{Ag}$ - $\mathrm{Au}$ посредством полиномов РедлихаКистера использовано ниже при расчете тройных твердых растворов $\mathrm{Ag}-\mathrm{Au}-\mathrm{Cu}$.

Таблица 1. Параметры уравнения Редлиха-Кистера для системы $\mathrm{Ag}-\mathrm{Cu}$

\begin{tabular}{c|c|c}
\hline Модель & ${ }^{0} L$, Дж/моль & ${ }^{1} L$, Дж/моль \\
\hline [He et al., 2006] & $32580.365-7.4547 T$ & $-10144.596+5.5617 T$ \\
[Dinsdale et al., 2008] & $36772.58-11.02847 \mathrm{~T}$ & $-4612.43+0.28869 \mathrm{~T}$
\end{tabular}

Таблица 2. Коэффициент корреляции $(\boldsymbol{R})$

\begin{tabular}{|c|c|c|c|c|c|c|c|c|c|c|}
\hline \multirow{2}{*}{ Минерал } & \multirow{2}{*}{$\begin{array}{c}\text { Состав твер- } \\
\text { дых растворов }\end{array}$} & \multirow{2}{*}{$\begin{array}{c}\Delta_{f} G^{0}, \\
\text { Дж/моль }\end{array}$} & \multirow{2}{*}{$\begin{array}{c}S^{0}, \\
\text { Дж/(моль } \cdot \mathrm{K})\end{array}$} & \multirow{2}{*}{$\begin{array}{c}V^{0}, \\
\mathrm{~cm}^{3} / \text { моль }\end{array}$} & \multirow{2}{*}{$T_{\max }, \mathrm{K}$} & \multicolumn{5}{|c|}{$C_{p}=a+b T+c T^{-2}+d T^{2}+g T^{-0.5}$} \\
\hline & & & & & & $a$ & $b \cdot 10^{-3}$ & $c \cdot 10^{5}$ & $d \cdot 10^{-6}$ & $g \cdot 10$ \\
\hline \multirow{7}{*}{$\begin{array}{l}\text { Медистое } \\
\text { серебро }\end{array}$} & $\mathrm{Ag}_{0}$ & 328 & 43.39 & 10.21 & 1215 & -2.05 & 20.36 & -5.22 & -2.79 & 46.949 \\
\hline & $\mathrm{Ag}_{0.96} \mathrm{Cu}_{0.04}^{0.02}$ & 710 & 43.98 & 10.15 & 1190 & 6.02 & 14.9 & -3.62 & -1.032 & 32.530 \\
\hline & $\mathrm{Ag}_{0.94} \mathrm{Cu}_{0.06}$ & 1101 & 44.48 & 10.08 & 1160 & 30.24 & -0.54 & 1.98 & 3.696 & -12.078 \\
\hline & $\mathrm{Ag}_{0.92} \mathrm{Cu}_{0.08}$ & 1494 & 44.91 & 10.02 & 1135 & 7.870 & 13.032 & -3.586 & -0.257 & 30.011 \\
\hline & $\mathrm{Ag}_{0.90} \mathrm{Cu}_{0.10}$ & 1882 & 45.28 & 9.96 & 1110 & 18.572 & 6.34 & -0.968 & 1.751 & 10.055 \\
\hline & $\mathrm{Ag}_{0.88} \mathrm{Cu}_{0.12}$ & 2263 & 45.61 & 9.89 & 1080 & 19.203 & 5.39 & -1.282 & 2.171 & 9.754 \\
\hline & $\mathrm{Ag}_{0.859} \mathrm{Cu}_{0.141}$ & 2654 & 45.92 & 9.83 & 1052 & 13.409 & 9.272 & -2.492 & 0.904 & 20.134 \\
\hline \multirow{3}{*}{$\begin{array}{c}\text { Серебрис- } \\
\text { тая медь }\end{array}$} & $\mathrm{Ag}_{0.049} \mathrm{Cu}_{0.951}$ & 1266 & 35.75 & 7.27 & 1052 & 43.139 & -17.632 & -0.952 & 10.854 & -23.753 \\
\hline & $\mathrm{Ag}_{0.04} \mathrm{Cu}_{0.96}$ & 1029 & 35.35 & 7.24 & 1140 & 77.42 & -39.6 & 7.02 & 17.676 & -86.891 \\
\hline & $\mathrm{Ag}_{0.02} \mathrm{Cu}_{0.98}$ & 498 & 34.36 & 7.18 & 1290 & 73.34 & -36.96 & 5.98 & 16.8 & -79.319 \\
\hline
\end{tabular}
активностей $\mathrm{Ag}$ и $\mathrm{Cu}$ расчетных моделей с экспериментальными данными [Hiltgren, 1963]

\begin{tabular}{c|c|c}
\hline Модель & $R\left(a_{\mathrm{Ag}}\right)$ & $R\left(a_{\mathrm{Cu}}\right)$ \\
\hline [He et al., 2006] & 0.9996 & 0.9908 \\
[Dinsdale et al., 2008] & 0.9979 & 0.9930
\end{tabular}

Таблица 3 .

Стандартные термодинамические свойства твердых растворов $\mathrm{Ag}-\mathrm{Cu}$ 


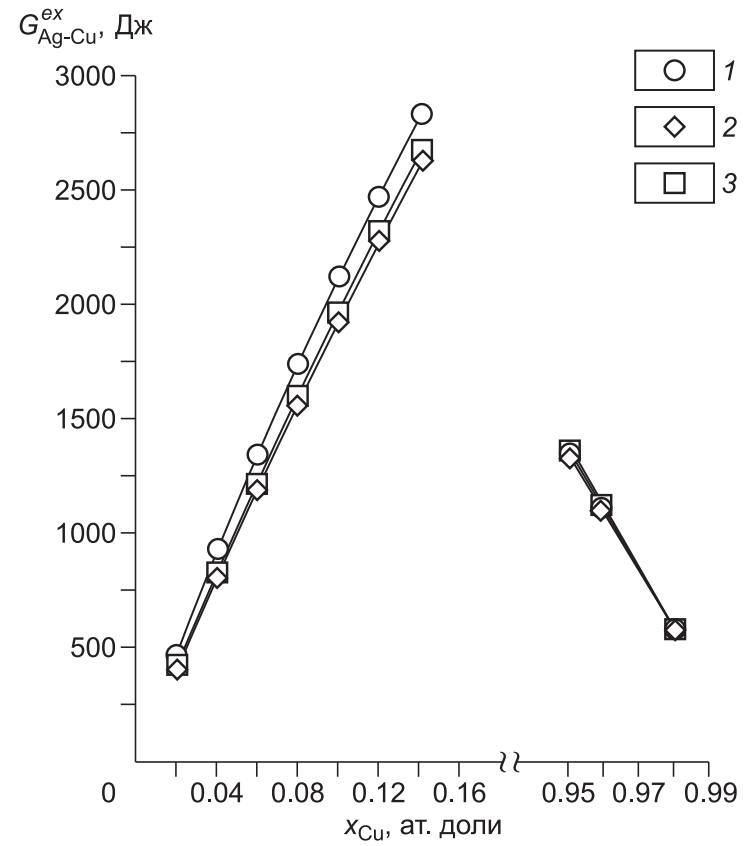

Рис. 3. Интегральная избыточная энергия твердого раствора $\mathrm{Ag}-\mathrm{Cu}(T=1052 \mathrm{~K})$.

1 - [Hiltgren,1963], 2 - [He et al., 2006], 3 - [Dinsdale et al., 2008].

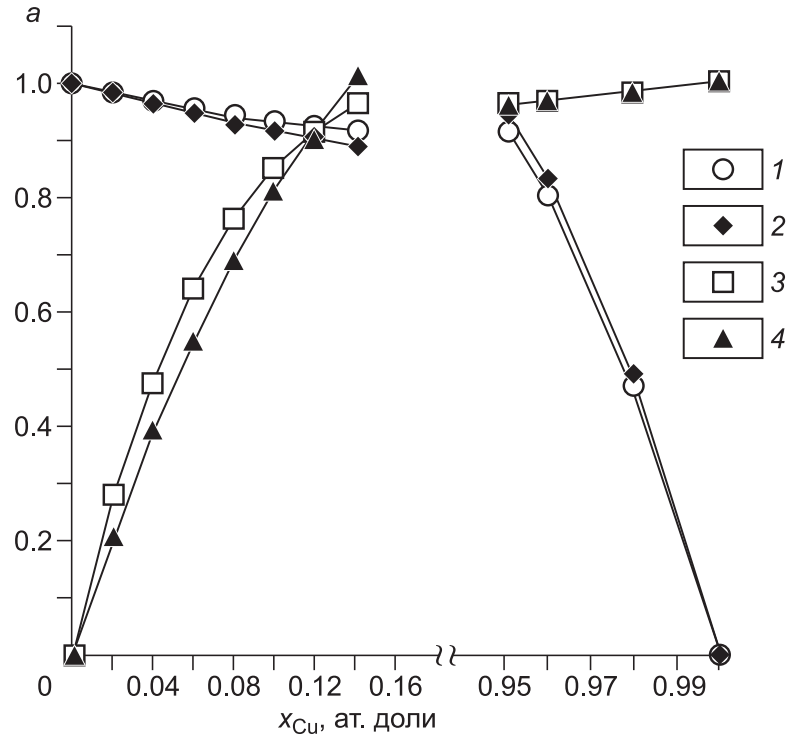

Рис. 4. Активности (a) серебра и меди $\mathrm{Ag}-\mathrm{Cu}$ твердого раствора в зависимости от состава $(T=1052 \mathrm{~K})$.

$1-a_{\mathrm{Ag}}$ [Hiltgren, 1963], $2-a_{\mathrm{Ag}}$ [Dinsdale et al., 2008], $3-a_{\mathrm{Cu}}$ [Hiltgren, 1963], $4-a_{\mathrm{Cu}}$ [Dinsdale et al., 2008].

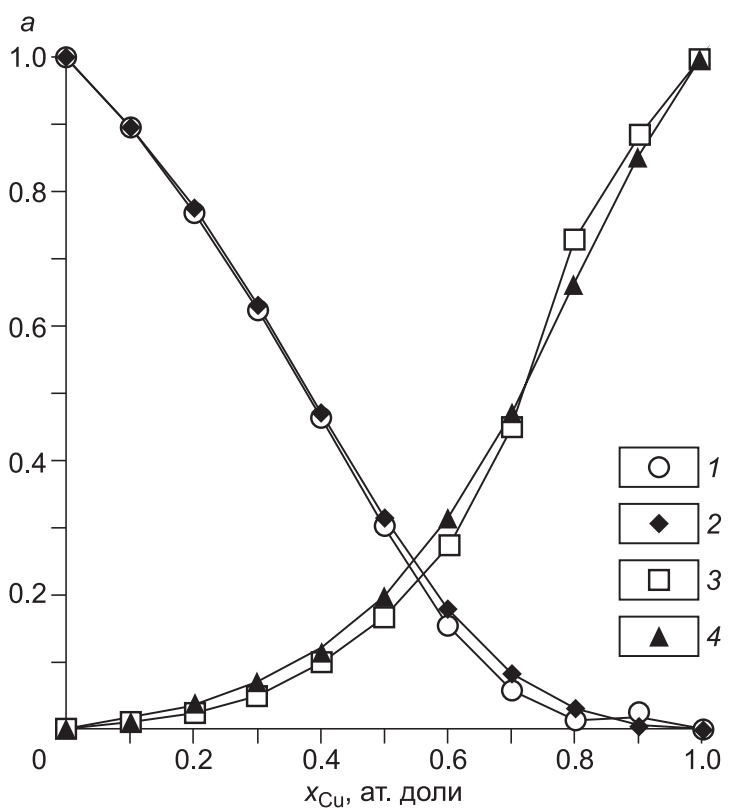

Рис. 6. Активности золота и меди $\mathrm{Au}-\mathrm{Cu}$ твердого раствора в зависимости от состава $(T=800 \mathrm{~K})$.

$1-a_{\mathrm{Au}}$ [Predel, 2005], $2-a_{\mathrm{Au}}$ [Sundman et al., 1998], $3-$ $a_{\mathrm{Cu}}$ [Predel, 2005], $4-a_{\mathrm{Cu}}$ [Sundman et al., 1998]. 
Таблица 4. Параметры уравнения Редлиха-Кистера для системы $\mathrm{Au}-\mathrm{Cu}$

\begin{tabular}{l|c|c}
\hline \multicolumn{1}{c|}{ Модель } & ${ }^{0} L$, Дж/моль & $\begin{array}{c}{ }^{1} L, \\
\text { Дж/моль }\end{array}$ \\
\hline $\begin{array}{l}\text { Аппроксимация урав- } \\
\text { нения из [Оkamoto et } \\
\text { al., 1987] } \\
\text { [Sundman et al., 1998] }\end{array}$ & $-28000+78.8 T-10 \mathrm{~T} \ln (T)$ & 6000
\end{tabular}

Та блица 5 . Коэффициент корреляции $(\boldsymbol{R})$ активностей Аu и Сu расчетных моделей с экспериментальными данными [Predel, 2005]

\begin{tabular}{c|c|c}
\hline Модель & $R\left(a_{\mathrm{Au}}\right)$ & $R\left(a_{\mathrm{Cu}}\right)$ \\
\hline [Okamoto et al., 1987] & 0.9992 & 0.9977 \\
[Sundman et al., 1998] & 0.9996 & 0.9975
\end{tabular}

Таблица $6 . \quad$ Стандартные термодинамические свойства твердых растворов $\mathrm{Au}-\mathrm{Cu}$

\begin{tabular}{|c|c|c|c|c|c|c|c|c|c|c|}
\hline \multirow{2}{*}{ Минерал } & \multirow{2}{*}{$\begin{array}{l}\text { Состав твер- } \\
\text { дых растворов }\end{array}$} & \multirow{2}{*}{$\begin{array}{c}\Delta_{f} G^{0}, \text { Дж/ } \\
\text { моль }\end{array}$} & \multirow{2}{*}{$\begin{array}{c}S^{0}, \text { Дж/ } \\
(\text { моль } \cdot \mathrm{K})\end{array}$} & \multirow{2}{*}{$\begin{array}{l}V^{0}, \mathrm{~cm}^{3} / \\
\text { моль }\end{array}$} & \multirow{2}{*}{$T_{\max }, \mathrm{K}$} & \multicolumn{5}{|c|}{$C_{p}=a+b T+c T^{-2}+d T^{2}+g T^{-0.5}$} \\
\hline & & & & & & $a$ & $b \cdot 10^{-3}$ & $c \cdot 10^{5}$ & $d \cdot 10^{-6}$ & $g \cdot 10$ \\
\hline \multirow{7}{*}{$\begin{array}{c}\text { Медистое } \\
\text { золото }\end{array}$} & $\mathrm{Au}_{096} \mathrm{Cu}_{0.04}$ & -1030 & 48.194 & 10.091 & 1300 & 65.86 & -32.76 & 5.32 & 15.900 & -64.778 \\
\hline & $\mathrm{Au}_{0.92}^{0.90} \mathrm{Cu}_{0.08}^{0.04}$ & -1902 & 48.433 & 9.967 & 1275 & 48.64 & -20.84 & 1.70 & 12.006 & -33.409 \\
\hline & $\mathrm{Au}_{0.9}^{0.92} \mathrm{Cu}_{01}^{0.08}$ & -2308 & 48.481 & 9.905 & 1265 & 69.72 & -35.50 & 5.40 & 16.860 & -69.823 \\
\hline & $\mathrm{Au}_{0.88}^{0.9} \mathrm{Cu}_{0.12}^{0.1}$ & -2698 & 48.494 & 9.843 & 1245 & 54.93 & -24.70 & 2.98 & 13.200 & -44.316 \\
\hline & $\mathrm{Au}_{0.84}^{0.80} \mathrm{Cu}_{0.16}^{0.12}$ & -3430 & 48.436 & 9.719 & 1225 & 65.25 & -32.00 & 4.44 & 15.672 & -61.273 \\
\hline & $\mathrm{Au}_{0.8} \mathrm{Cu}_{0.2}$ & -4103 & 48.288 & 9.595 & 1215 & 49.67 & -21.86 & 0.88 & 12.576 & -32.260 \\
\hline & $\mathrm{Au}_{0.76}{ }^{.0} \mathrm{Cu}_{0.24}$ & -4717 & 48.067 & 9.471 & 1200 & 45.13 & -18.20 & 0.00 & 11.216 & -24.184 \\
\hline \multirow{7}{*}{$\begin{array}{c}\text { Золотистая } \\
\text { медь }\end{array}$} & $\mathrm{Au}_{0.24} \mathrm{Cu}_{0.76}$ & -5856 & 40.605 & 7.857 & 1220 & 61.33 & -28.24 & 3.24 & 14.196 & -54.068 \\
\hline & $\mathrm{Au}_{0.2}^{0.24} \mathrm{Cu}_{0.8}^{0.10}$ & -5255 & 39.678 & 7.733 & 1240 & 51.54 & -22.50 & 0.66 & 12.516 & -35.866 \\
\hline & $\mathrm{Au}_{0.16} \mathrm{Cu}_{0.84}^{0.0}$ & -4527 & 38.678 & 7.609 & 1255 & 72.47 & -36.14 & 5.36 & 16.746 & -74.578 \\
\hline & $\mathrm{Au}_{0.12}^{0.16} \mathrm{Cu}_{0.88}^{0.84}$ & -3661 & 37.588 & 7.485 & 1275 & 78.40 & -40.10 & 6.72 & 17.952 & -86.011 \\
\hline & $\mathrm{Au}_{0.1} \mathrm{Cu}_{0.9}$ & -3172 & 37.001 & 7.423 & 1285 & 59.96 & -27.88 & 2.86 & 14.016 & -53.117 \\
\hline & $\mathrm{Au}_{0.08} \mathrm{Cu}_{0.92}$ & -2644 & 36.379 & 7.361 & 1305 & 66.71 & -32.68 & 4.20 & 15.624 & -65.310 \\
\hline & $\mathrm{Au}_{0.04} \mathrm{Cu}_{0.96}$ & -1454 & 34.992 & 7.237 & 1340 & 72.41 & -36.26 & 5.58 & 16.602 & -76.653 \\
\hline
\end{tabular}

Бинарная система $\mathrm{Au}-\mathrm{Cu}$. Компоненты системы $\mathrm{Au}-\mathrm{Cu}$ неограниченно растворимы в жидком состоянии и образуют непрерывный ряд твердых растворов [Диаграммы..., 1996]. Х. Окамото с соавторами [Okamoto et al., 1987] предложен кубический полином для расчета избыточной энергии Гиббса. На предварительной стадии была выполнена серия расчетов по этому полиному и путем аппроксимации получены параметры уравнения Редлиха-Кистера $(R=0.9985)$. Значения рассчитанных и предложенных в работе [Sundman et al., 1998] параметров представлены в табл. 4. Величины интегральной избыточной энергии твердых растворов системы $\mathrm{Au}-\mathrm{Cu}$, вычисленные по уравнению (3), и данные эксперимента [Hultgren, 1963] для температуры 720К показаны на рис. 5. Максимальные отклонения не превышают 500 Дж/моль.

Вычисленные по уравнениям (4), (5) с параметрами [Sundman et al., 1998] и [Okamoto et al., 1987] и снятые с диаграммы экспериментальных данных [Predel, 2005] значения активностей Аu и Сu имеют близкие значения на всем интервале возможных составов твердого раствора $\mathrm{Au}-\mathrm{Cu}$ (рис. 6). Оценка коэффициентов корреляции активностей $\mathrm{Au}$ и $\mathrm{Cu}$ расчетных моделей с экспериментальными данными (табл. 5) стала основой выбора параметров уравнения Редлиха-Кистера из модели [Sundman et al., 1998], которые были использованы в расчете стандартных термодинамических характеристик твердых растворов $\mathrm{Au}-\mathrm{Cu}$ (табл. 6). Там же приведены верхние пределы по температуре действия расчетных параметров.

\section{ТЕРМОДИНАМИЧЕСКОЕ ОПИСАНИЕ ТРОЙНОЙ СИСТЕМЫ $\mathrm{Ag}-\mathrm{Au}-\mathrm{Cu}$}

Термодинамические свойства тройной системы $\mathrm{Ag}-\mathrm{Au}-\mathrm{Cu}$ рассчитывались на основании данных о граничных двойных системах с предположением, что рассматриваемая система представляет собой субрегулярный твердый раствор.

Энергия Гиббса одного моля твердого раствора $\mathrm{Au}_{x_{3}} \mathrm{Ag}_{x_{2}} \mathrm{Cu}_{x_{1}}$ при давлении 1 бар и температуре $T$ рассчитывалась по уравнению:

$$
G=G^{e x}+x_{1} G_{1}^{0}+x_{2} G_{2}^{0}+x_{3} G_{3}^{0}+G^{i d},
$$

где энергия Гиббса идеального смешения $G^{i d}=R T\left(x_{1} \ln x_{1}+x_{2} \ln x_{2}+x_{3} \ln x_{3}\right), G_{i}^{0}(i=1,2,3)$ энергии Гиббса металлов в стандартных условиях [Robie, Hemingway, 1995], $x_{1}, x_{2}, x_{3}$ - атомные доли соответственно $\mathrm{Cu}, \mathrm{Ag}, \mathrm{Au}$. 
Таблица $7 . \quad$ Стандартные термодинамические свойства твердых растворов $\mathbf{A g}-\mathbf{A u}-\mathbf{C u}$

\begin{tabular}{|c|c|c|c|c|c|c|c|c|c|}
\hline \multirow{2}{*}{ Минерал } & \multirow{2}{*}{$\begin{array}{c}\text { Состав твердых } \\
\text { растворов }\end{array}$} & \multirow{2}{*}{$\begin{array}{c}\Delta_{f} G^{0}, \\
\text { Дж/моль }\end{array}$} & \multirow{2}{*}{$\begin{array}{c}S^{0}, \\
\text { Дж/(моль } \cdot \mathrm{K})\end{array}$} & \multirow{2}{*}{ 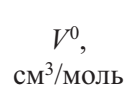 } & \multicolumn{5}{|c|}{$C_{p}=a+b T+c T^{-2}+d T^{2}+g T^{-0.5}$} \\
\hline & & & & & $a$ & $b \cdot 10^{-3}$ & $c \cdot 10^{5}$ & $d \cdot 10^{-6}$ & $g \cdot 10$ \\
\hline \multirow{23}{*}{$\begin{array}{c}\text { Медистое вы- } \\
\text { сокопробное } \\
\text { золото }\end{array}$} & $\mathrm{Au}_{0.92} \mathrm{Ag}_{0.04} \mathrm{Cu}_{0.04}$ & -1939 & 49.347 & 10.093 & 49.80 & -22.14 & 1.78 & 12.534 & -35.707 \\
\hline & $\mathrm{Au}_{0.88} \mathrm{Ag}_{0.04} \mathrm{Cu}_{0.08}$ & -2712 & 49.748 & 9.969 & 50.87 & -22.58 & 1.90 & 12.66 & -37.041 \\
\hline & $\mathrm{Au}_{0.88} \mathrm{Ag}_{0.08} \mathrm{Cu}_{0.04}$ & -2667 & 49.879 & 10.095 & 48.11 & -20.66 & 1.60 & 11.982 & -33.138 \\
\hline & $\mathrm{Au}_{0.84} \mathrm{Ag}_{0.04} \mathrm{Cu}_{0.12}$ & -3405 & 49.955 & 9.845 & 51.88 & -23.02 & 2.00 & 12.774 & -38.311 \\
\hline & $\mathrm{Au}_{0.84} \mathrm{Ag}_{0.08} \mathrm{Cu}_{0.08}$ & -3339 & 50.289 & 9.971 & 49.03 & -21.02 & 1.68 & 12.084 & -34.219 \\
\hline & $\mathrm{Au}_{0.84} \mathrm{Ag}_{0.12} \mathrm{Cu}_{0.04}$ & -3297 & 50.240 & 10.098 & 46.12 & -19.00 & 1.36 & 11.376 & -30.018 \\
\hline & $\mathrm{Au}_{0.80} \mathrm{Ag}_{0.04} \mathrm{Cu}_{0.16}^{0.04}$ & -4031 & 50.029 & 9.721 & 52.92 & -23.48 & 2.12 & 12.906 & -39.713 \\
\hline & $\mathrm{Au}_{0.80} \mathrm{Ag}_{0.08} \mathrm{Cu}_{0.12}$ & -3927 & 50.506 & 9.847 & 50.14 & -21.52 & 1.82 & 12.222 & -35.718 \\
\hline & $\mathrm{Au}_{0.80} \mathrm{Ag}_{0.12} \mathrm{Cu}_{0.08}$ & -3867 & 50.659 & 9.974 & 47.34 & -19.56 & 1.52 & 11.538 & -31.689 \\
\hline & $\mathrm{Au}_{0.80} \mathrm{Ag}_{0.16} \mathrm{Cu}_{0.04}$ & -3846 & 50.491 & 10.100 & 44.55 & -17.60 & 1.20 & 10.854 & -27.665 \\
\hline & $\mathrm{Au}_{0.76} \mathrm{Ag}_{0.04} \mathrm{Cu}_{0.2}$ & -4594 & 50.000 & 9.597 & 53.87 & -23.92 & 2.24 & 13.032 & -41.010 \\
\hline & $\mathrm{Au}_{0.76} \mathrm{Ag}_{0.2} \mathrm{Cu}_{0.04}$ & -4321 & 50.659 & 10.102 & 42.645 & -15.982 & 0.976 & 10.262 & -24.708 \\
\hline & $\mathrm{Au}_{0.76} \mathrm{Ag}_{0.16} \mathrm{Cu}_{0.08}$ & -4313 & 50.918 & 9.976 & 45.46 & -17.98 & 1.30 & 10.956 & -28.807 \\
\hline & $\mathrm{Au}_{0.72} \mathrm{Ag}_{0.24} \mathrm{Cu}_{0.04}$ & -4725 & 50.761 & 10.105 & 41.041 & -14.562 & 0.814 & 9.732 & -22.296 \\
\hline & $\mathrm{Au}_{0.72} \mathrm{Ag}_{0.2} \mathrm{Cu}_{0.08}$ & -4684 & 51.094 & 9.978 & 43.53 & -16.34 & 1.06 & 10.362 & -25.818 \\
\hline & $\mathrm{Au}_{0.68}^{0.72} \mathrm{Ag}_{0.28} \mathrm{Cu}_{0.04}$ & -5061 & 50.807 & 10.107 & 39.110 & -12.934 & 0.578 & 9.138 & -19.286 \\
\hline & $\mathrm{Au}_{0.68} \mathrm{Ag}_{0.24} \mathrm{Cu}_{0.08}$ & -4983 & 51.202 & 9.981 & 42.046 & -15.018 & 0.934 & 9.860 & -23.663 \\
\hline & $\mathrm{Au}_{0.64} \mathrm{Ag}_{0.32} \mathrm{Cu}_{0.04}$ & -5329 & 50.805 & 10.109 & 37.524 & -11.52 & 0.424 & 8.609 & -16.913 \\
\hline & $\mathrm{Au}_{0.64} \mathrm{Ag}_{0.28} \mathrm{Cu}_{0.08}$ & -5212 & 51.253 & 9.983 & 40.090 & -13.382 & 0.696 & 9.263 & -20.637 \\
\hline & $\mathrm{Au}_{0.6} \mathrm{Ag}_{0.36} \mathrm{Cu}_{0.04}$ & -5529 & 50.758 & 10.111 & 35.654 & -9.932 & 0.204 & 8.027 & -14.015 \\
\hline & $\mathrm{Au}_{0.6} \mathrm{Ag}_{0.32} \mathrm{Cu}_{0.08}$ & -5373 & 51.255 & 9.985 & 38.383 & -11.904 & 0.516 & 8.715 & -18.068 \\
\hline & $\mathrm{Au}_{0.56} \mathrm{Ag}_{0.4} \mathrm{Cu}_{0.04}$ & -5661 & 50.671 & 10.114 & 33.667 & -8.27 & -0.046 & 7.423 & -10.896 \\
\hline & $\mathrm{Au}_{0.56} \mathrm{Ag}_{0.36} \mathrm{Cu}_{0.08}$ & -5464 & 51.211 & 9.987 & 36.937 & -10.594 & 0.398 & 8.2182 & -15.983 \\
\hline \multirow{20}{*}{$\begin{array}{c}\text { Медистый } \\
\text { электрум }\end{array}$} & $\mathrm{Au}_{0.52} \mathrm{Ag}_{0.44} \mathrm{Cu}_{0.04}$ & -5724 & 50.544 & 10.116 & 32.080 & -6.852 & -0.198 & 6.891 & -8.529 \\
\hline & $\mathrm{Au}_{0.52} \mathrm{Ag}_{0.4} \mathrm{Cu}_{0.08}$ & -5486 & 51.124 & 9.990 & 34.844 & -8.874 & 0.128 & 7.596 & -12.700 \\
\hline & $\mathrm{Au}_{0.48} \mathrm{Ag}_{0.48} \mathrm{Cu}_{0.04}$ & -5718 & 50.381 & 10.118 & 30.326 & -5.336 & -0.392 & 6.332 & -5.844 \\
\hline & $\mathrm{Au}_{0.48} \mathrm{Ag}_{0.44} \mathrm{Cu}_{0.08}$ & -5438 & 50.997 & 9.992 & 33.175 & -7.412 & -0.036 & 7.05 & -10.216 \\
\hline & $\mathrm{Au}_{0.44} \mathrm{Ag}_{0.52} \mathrm{Cu}_{0.04}$ & -5641 & 50.180 & 10.121 & 28.640 & -3.864 & -0.572 & 5.785 & -3.283 \\
\hline & $\mathrm{Au}_{0.44} \mathrm{Ag}_{0.48} \mathrm{Cu}_{0.08}$ & -5318 & 50.830 & 9.994 & 32.518 & -6.62 & 0.014 & 6.717 & -9.559 \\
\hline & $\mathrm{Au}_{0.4} \mathrm{Ag}_{0.56} \mathrm{Cu}_{0.04}$ & -5491 & 49.941 & 10.123 & 26.893 & -2.35 & -0.764 & 5.226 & -0.613 \\
\hline & $\mathrm{Au}_{0.4} \mathrm{Ag}_{0.52} \mathrm{Cu}_{0.08}$ & -5126 & 50.623 & 9.996 & 29.570 & -4.344 & -0.446 & 5.921 & -4.717 \\
\hline & $\mathrm{Au}_{0.36} \mathrm{Ag}_{0.6} \mathrm{Cu}_{0.04}$ & -5268 & 49.664 & 10.125 & 24.929 & -0.698 & -1.005 & 4.624 & 2.455 \\
\hline & $\mathrm{Au}_{0.36} \mathrm{Ag}_{0.56} \mathrm{Cu}_{0.08}$ & -4861 & 50.376 & 9.999 & 27.491 & -2.628 & -0.708 & 5.2986 & -1.467 \\
\hline & $\mathrm{Au}_{0.32} \mathrm{Ag}_{0.64} \mathrm{Cu}_{0.04}$ & -4969 & 49.346 & 10.127 & 23.360 & 0.699 & -1.158 & 4.101 & 4.802 \\
\hline & $\mathrm{Au}_{0.32} \mathrm{Ag}_{0.6} \mathrm{Cu}_{0.08}$ & -4519 & 50.086 & 10.001 & 26.025 & -1.304 & -0.832 & 4.798 & 0.658 \\
\hline & $\mathrm{Au}_{0.28} \mathrm{Ag}_{0.68} \mathrm{Cu}_{0.04}$ & -4591 & 48.984 & 10.130 & 21.546 & 2.255 & -1.366 & 3.529 & 7.597 \\
\hline & $\mathrm{Au}_{0.28} \mathrm{Ag}_{0.64} \mathrm{Cu}_{0.08}$ & -4099 & 49.751 & 10.003 & 24.193 & 0.248 & -1.044 & 4.228 & 3.462 \\
\hline & $\mathrm{Au}_{0.24} \mathrm{Ag}_{0.72} \mathrm{Cu}_{0.04}$ & -4133 & 48.573 & 10.132 & 19.267 & 4.112 & -1.676 & 2.862 & 11.239 \\
\hline & $\mathrm{Au}_{0.24}^{0.24} \mathrm{Ag}_{0.68} \mathrm{Cu}_{0.08}^{0.04}$ & -3599 & 49.366 & 10.006 & 21.937 & 2.08 & -1.346 & 3.569 & 7.033 \\
\hline & $\mathrm{Au}_{0.2} \mathrm{Ag}_{0.76} \mathrm{Cu}_{0.04}$ & -3591 & 48.107 & 10.134 & 18.043 & 5.286 & -1.752 & 2.409 & 12.953 \\
\hline & $\mathrm{Au}_{0.2} \mathrm{Ag}_{0.72} \mathrm{Cu}_{0.08}$ & -3015 & 48.923 & 10.008 & 20.633 & 3.296 & -1.436 & 3.103 & 8.865 \\
\hline & $\mathrm{Au}_{0.16}^{0.2} \mathrm{Ag}_{0.80} \mathrm{Cu}_{0.04}$ & -2961 & 47.574 & 10.137 & 16.263 & 6.821 & -1.952 & 1.843 & 15.686 \\
\hline & $\mathrm{Au}_{0.16} \mathrm{Ag}_{0.76} \mathrm{Cu}_{0.08}$ & -2343 & 48.414 & 10.010 & 18.656 & 4.946 & -1.676 & 2.501 & 11.928 \\
\hline \multirow{9}{*}{$\begin{array}{l}\text { Медистый } \\
\text { кюстелит }\end{array}$} & $\mathrm{Au}_{0.04} \mathrm{Ag}_{0.92} \mathrm{Cu}_{0.04}$ & -454 & 45.337 & 10.143 & 10.499 & 11.697 & -2.645 & 0.060 & 24.653 \\
\hline & $\mathrm{Au}_{0.04} \mathrm{Ag}_{0.88} \mathrm{Cu}_{0.08}$ & 289 & 46.242 & 10.017 & 13.386 & 9.472 & -2.248 & 0.828 & 19.904 \\
\hline & $\mathrm{Au}_{0.08} \mathrm{Ag}_{0.88} \mathrm{Cu}_{0.04}$ & -1406 & 46.233 & 10.141 & 12.658 & 9.915 & -2.363 & 0.704 & 21.233 \\
\hline & $\mathrm{Au}_{0.04} \mathrm{Ag}_{0.84} \mathrm{Cu}_{0.12}$ & 1015 & 46.925 & 9.891 & 15.863 & 7.516 & -1.942 & 1.511 & 15.904 \\
\hline & $\mathrm{Au}_{0.08} \mathrm{Ag}_{0.84} \mathrm{Cu}_{0.08}$ & -705 & 47.118 & 10.015 & 15.241 & 7.90 & -2.036 & 1.405 & 17.066 \\
\hline & $\mathrm{Au}_{0.12} \mathrm{Ag}_{0.84} \mathrm{Cu}_{0.04}$ & -2236 & 46.959 & 10.139 & 14.488 & 8.3514 & -2.150 & 1.278 & 18.407 \\
\hline & $\mathrm{Au}_{0.04} \mathrm{Ag}_{0.80} \mathrm{Cu}_{0.16}$ & 1703 & 47.446 & 9.7643 & 18.344 & 5.556 & -1.636 & 2.195 & 11.896 \\
\hline & $\mathrm{Au}_{0.08} \mathrm{Ag}_{0.80} \mathrm{Cu}_{0.12}$ & -23 & 47.779 & 9.888 & 17.722 & 5.952 & -1.732 & 2.086 & 13.087 \\
\hline & $\mathrm{Au}_{0.12} \mathrm{Ag}_{0.80} \mathrm{Cu}_{0.08}^{0.12}$ & -1576 & 47.822 & 10.012 & 16.907 & 6.452 & -1.866 & 1.945 & 14.573 \\
\hline \multirow{6}{*}{$\begin{array}{c}\text { Золотистая } \\
\text { медь }\end{array}$} & $\mathrm{Au}_{0.24} \mathrm{Ag}_{0.04} \mathrm{Cu}_{0.72}$ & -5072 & 43.321 & 7.984 & 63.30 & -29.52 & 3.66 & 14.598 & -57.812 \\
\hline & $\mathrm{Au}_{0.20} \mathrm{Ag}_{0.04} \mathrm{Cu}_{0.76}$ & -4428 & 42.345 & 7.860 & 63.76 & -29.92 & 3.76 & 14.706 & -59.025 \\
\hline & $\mathrm{Au}_{0.16} \mathrm{Ag}_{0.04} \mathrm{Cu}_{0.8}$ & -3657 & 41.282 & 7.736 & 64.20 & -30.34 & 3.86 & 14.826 & -60.273 \\
\hline & $\mathrm{Au}_{0.12}^{0.16} \mathrm{Ag}_{0.04} \mathrm{Cu}_{0.84}$ & -2749 & 40.114 & 7.612 & 64.67 & -30.80 & 3.98 & 14.952 & -61.632 \\
\hline & $\mathrm{Au}_{0.08} \mathrm{Ag}_{0.04} \mathrm{Cu}_{0.88}$ & -1691 & 38.813 & 7.488 & 65.09 & -31.24 & 4.08 & 15.072 & -62.949 \\
\hline & $\mathrm{Au}_{0.04} \mathrm{Ag}_{0.04} \mathrm{Cu}_{0.92}$ & -462 & 37.319 & 7.363 & 65.36 & -31.60 & 4.18 & 15.174 & -64.051 \\
\hline
\end{tabular}


Избыточная энергия Гиббса тройной системы определялась как сумма парциальных избыточных энергий бинарных твердых растворов, вычисленных с использованием полиномов Редлиха-Кистера [Hillert, 2008]:

$$
G^{e x}=x_{1} G_{1}^{e x}+x_{2} G_{2}^{e x}+x_{3} G_{3}^{e x},
$$

где

$$
\begin{gathered}
G_{1}^{e x}=x_{2}\left(x_{2}+x_{3}\right) L_{12}-x_{2} x_{3} L_{23}+x_{3}\left(x_{3}+x_{2}\right) L_{31}, \\
G_{2}^{e x}=x_{1}\left(x_{1}+x_{3}\right) L_{12}+x_{3}\left(x_{3}+x_{1}\right) L_{23}-x_{3} x_{1} L_{31}, \\
G_{3}^{e x}=-x_{1} x_{2} L_{12}+x_{2}\left(x_{2}+x_{1}\right) L_{23}+x_{1}\left(x_{1}+x_{2}\right) L_{31} .
\end{gathered}
$$

Уравнения (14) - (17) позволяют получить результаты, совпадающие с расчетами по широко используемой симметричной модели Муггиани [Muggianu et al., 1975]. Избыточные энергии Гиббса бинарных растворов определялись по уравнениям (15) - (17) с соответствующими параметрами Редлиха-Кистера: $\mathrm{Ag}-\mathrm{Cu}$ [Dinsdale et al., 2008], $\mathrm{Ag}-\mathrm{Au}$ [White et al., 1957] и $\mathrm{Au}-\mathrm{Cu}$ [Sundman et al., 1998]. Стандартные энтропии твердых растворов $\mathrm{Ag}-\mathrm{Au}-\mathrm{Cu}$ были рассчитаны по уравнению:

$$
S_{T}^{0}=S^{e x}+x_{1} S_{\mathrm{Cu}}^{0}+x_{2} S_{\mathrm{Ag}}^{0}+x_{3} S_{\mathrm{Au}}^{0}+S^{i d},
$$

где $S_{\mathrm{Cu}}^{0}, S_{\mathrm{Ag}}^{0}, S_{\mathrm{Au}}^{0}$ - стандартные энтропии $\mathrm{Cu}, \mathrm{Ag}$ и $\mathrm{Au}$ [Robie, Hemingway, 1995]; $S^{\text {id }}$ - энтропия идеального смешения, равная $-R\left(x_{1} \ln x_{1}+x_{2} \ln x_{2}+x_{3} \ln x_{3}\right)$; избыточная энтропия смешения $S^{e x}$ определялась по уравнению (11).

Мольный объем тройных твердых растворов был вычислен по правилу Ретгерса на основе мольных объемов чистых металлов [Robie, Hemingway, 1995]:

$$
V\left(\mathrm{Au}_{x 3} \mathrm{Ag}_{x 2} \mathrm{Cu}_{x 1}\right)=x_{3} V_{\mathrm{Au}}^{0}+x_{2} V_{\mathrm{Ag}}^{0}+x_{1} V_{\mathrm{Cu}}^{0} .
$$

Коэффициенты активности в твердых растворах $\mathrm{Ag}-\mathrm{Au}-\mathrm{Cu}$ оцениваются на основе избыточных парциальных энергий Гиббса (15)—(17):

$$
\begin{gathered}
\ln \gamma_{\mathrm{Cu}}=\left[x_{\mathrm{Ag}}\left(x_{\mathrm{Ag}}+x_{\mathrm{Au}}\right) L_{\mathrm{CuAg}}-x_{\mathrm{Ag}} \mathrm{x}_{\mathrm{Au}} L_{\mathrm{AgAu}}+x_{\mathrm{Au}}\left(x_{\mathrm{Au}}+x_{\mathrm{Ag}}\right) L_{\mathrm{AuCu}}\right] /(R T), \\
\ln \gamma_{\mathrm{Ag}}=\left[x_{\mathrm{Cu}}\left(x_{\mathrm{Cu}}+x_{\mathrm{Au}}\right) L_{\mathrm{CuAg}}+x_{\mathrm{Au}}\left(x_{\mathrm{Au}}+x_{\mathrm{Cu}}\right) L_{\mathrm{AgAu}}-x_{\mathrm{Au}} x_{\mathrm{Cu}} L_{\mathrm{AuCu}}\right] /(R T), \\
\ln \gamma_{\mathrm{Au}}=\left[-x_{\mathrm{Cu}} x_{\mathrm{Ag}} L_{\mathrm{CuAg}}+x_{\mathrm{Ag}}\left(x_{\mathrm{Ag}}+x_{\mathrm{Cu}}\right) L_{\mathrm{AgAu}}+x_{\mathrm{Cu}}\left(x_{\mathrm{Cu}}+x_{\mathrm{Ag}}\right) L_{\mathrm{AuCu}}\right] /(R T) .
\end{gathered}
$$

В табл. 7 представлены термодинамические характеристики $\mathrm{Ag}-\mathrm{Au}-\mathrm{Cu}$ твердых растворов для составов с шагом 0.04 ат. доли каждого из металлов.

\section{ЗАКЛЮЧЕНИЕ}

Состав самородного золота, как и любого другого минерала, служит источником информации о физико-химических условиях рудоотложения. Выявление причинно-следственных связей между характеристиками минералообразующих процессов и составом минерала является важнейшей задачей генетической минералогии [Самусиков, 2010] и физико-химического моделирования.

Система $\mathrm{Ag}-\mathrm{Au}-\mathrm{Cu}$, имеющая практически важное значение в металлургии, геохимии, ювелирном деле и др., достаточно детально изучена как в плане кристаллографии, так и термодинамики бинарных и тройных систем твердых растворов. Между тем специфика различного вида приложений предполагает выбор используемых подходов и методов исследования. Так, например, металлургов в большей степени интересовало поведение компонентов в расплаве, и термодинамика растворов в системе оценивалась именно с этих позиций. Систематизированной сводки данных в системе $\mathrm{Ag}-\mathrm{Au}-\mathrm{Cu}$ в формате термодинамических баз данных, используемых в моделировании природных физико-химических процессов на основе метода минимизации энергии Гиббса, до сих пор предложено не было. Выполненные в настоящей работе исследования заполняют данный пробел. В результате проведенных расчетов подготовлена представительная сводка термодинамических свойств твердых растворов системы $\mathrm{Ag}-\mathrm{Au}-\mathrm{Cu}$, включающая все основные разновидности, характерные для природных систем (рис. 7), что может способствовать проведению более точных расчетов в моделировании процессов формирования месторождений медистого золота и серебра.

Представленный в данной работе обзор месторождений, рудопроявлений и других геологических объектов свидетельствует о частых находках $\mathrm{Ag}-\mathrm{Au}-\mathrm{Cu}$ твердых растворов и возможном более широком их распространении. Исследуемая рудная триада является важнейшей с минералогической точки зре- 


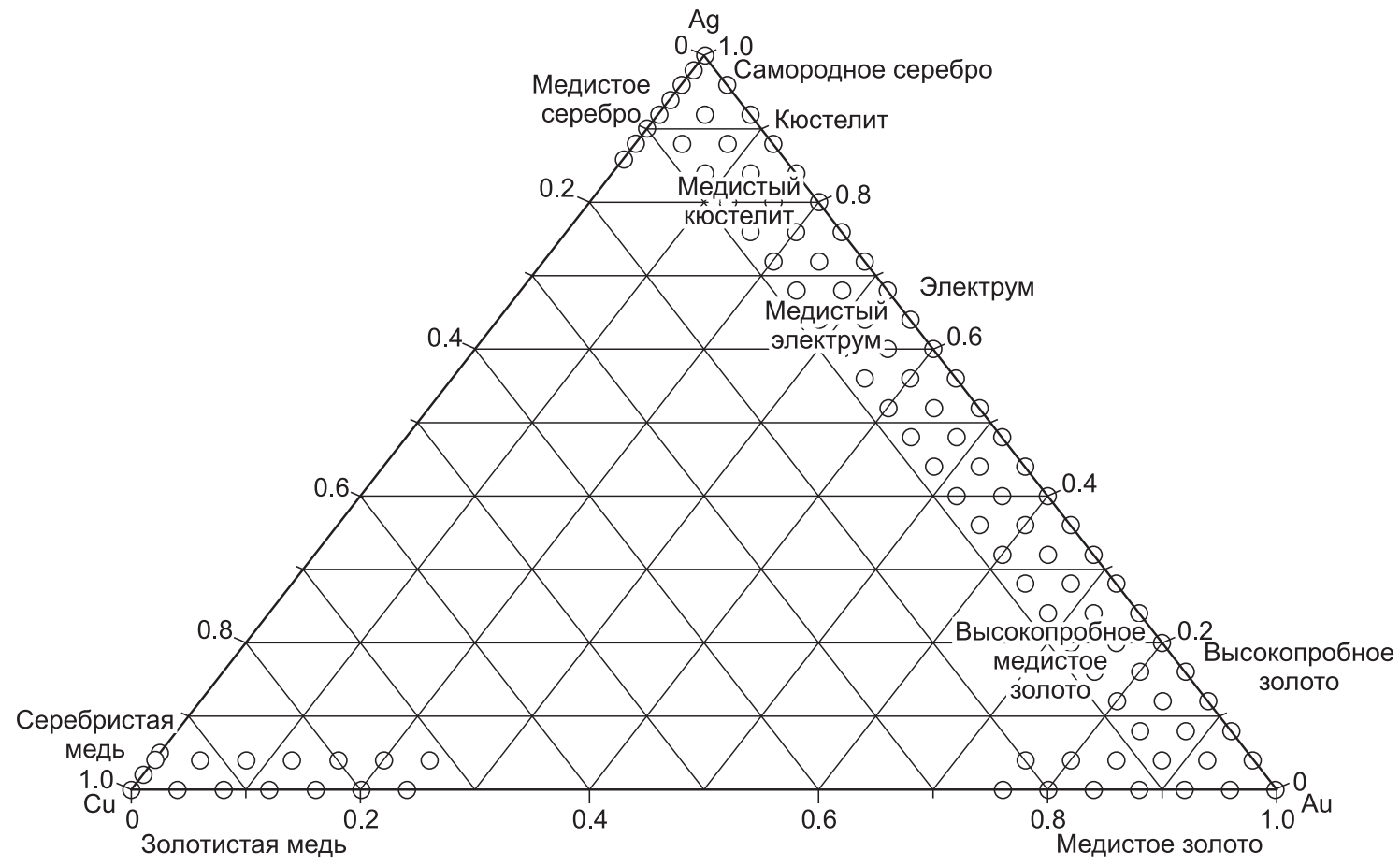

Рис. 7. Составы твердых растворов (ат. доли), для которых выполнена оценка стандартных термодинамических функций:

бинарные системы $\mathrm{Ag}$ - $\mathrm{Au}$ [Пальянова и др., 2005], $\mathrm{Au}-\mathrm{Cu}, \mathrm{Ag}-\mathrm{Cu}$ и тройная система $\mathrm{Ag}-\mathrm{Au}-\mathrm{Cu}$ (данная работа).

ния, поскольку медистое золото и другие твердые растворы, содержащие $\mathrm{Ag}$, $\mathrm{Au}$ и $\mathrm{Cu}$, часто встречаются на месторождениях разного генезиса и служат индикаторами генетической связи золотого, серебряного и медного оруденений. Подготовленная сводка термодинамических данных для твердых растворов системы $\mathrm{Ag}$ - $\mathrm{Au}$ - $\mathrm{Cu}$ позволяет разрабатывать более адекватные физико-химические модели рудообразующих процессов с участием всех трех металлов. Включение трехкомпонентных твердых растворов в качестве потенциально возможных фаз при расчете равновесных минеральных ассоциаций в заданных $T, P$-условиях позволит проводить термодинамическое моделирование и строить модели формирования

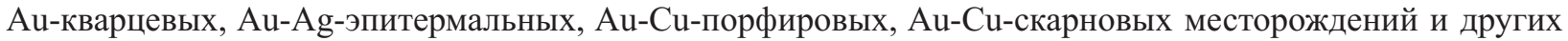
объектов с повышенными содержаниями золота, серебра и меди, а также прогнозировать наличие примесей меди в самородных золоте и серебре, а также серебра и золота в самородной меди. Поскольку $\mathrm{Ag}-\mathrm{Au}-\mathrm{Cu}$ твердые растворы широко развиты в разнообразных базит-гипербазитовых комплексах, а также в серпентинизированных породах, то необходимо учитывать возможность их образования в более высокотемпературных процессах с целью выявления их поведения при дифференциации рудного вещества. Предложенный метод оценки стандартных термодинамических характеристик может быть использован и для других твердых растворов бинарных и тройных систем.

Работа выполнена при поддержке СО РАН (проекты № 12 и 48).

Авторы выражают благодарность В.С. Урусову, В.И. Косякову и И.А. Киселевой за ряд ценных замечаний, учтенных в подготовке окончательного текста рукописи.

\section{ЛИТЕРАТУРА}

Акинфиев Н.Н., Зотов А.В. Термодинамическое описание водных компонентов системы $\mathrm{Cu}-\mathrm{Ag}-$ $\mathrm{Au}-\mathrm{S}-\mathrm{O}-\mathrm{H}$ в диапазоне температур $0-600{ }^{\circ} \mathrm{C}$ и $1-3000$ бар // Геохимия, 2010, № 7, с. 761-767. 839 c.

Вернадский В.И. Опыт описательной минералогии. Т. 1. Самородные элементы. СПб., 1914,

Викентьева О.В., Тюкова Е.Э. Самородное золото мезотермальных золоторудных месторождений // Минералогия Урала-2007, Миасс-Екатеринбург, 2007, с. 137-140.

Вол А.Е., Коган И.К. Строение и свойства двойных металлических систем. Т. 3, М., Наука, 1976, 814 c. 
Годовиков А.А. Минералогия. М., Недра, 1975, 520 с.

Дамдинов Б.Б. Нетрадиционные типы благороднометалльной минерализации в офиолитах Восточно-Саянского и Джидинского поясов: Автореф. дис. ... к.г.-м.н. Улан-Удэ, 2004, 24 с.

Диаграммы состояния двойных металлических систем: справочник. В 3 т. Т. 1 / Ред. Н.П. Лякишев. М., Машиностроение, 1996, 992 с.

Жмодик С.М., Миронов А.Г., Жмодик А.С. Золотоконцентрирующие системы офиолитовых поясов (на примере Саяно-Байкало-Муйского пояса). Новосибирск, Изд-во «Гео», 2008, 304 с.

Казаченко В.Т., Мирошниченко Н.В., Перевозникова Е.В., Карабцов А.А. Минеральные формы благородных металлов в металлоносных отложениях триасово-юрской углеродистой толщи СихотэАлиня // Докл. РАН, 2008, т. 421, № 3, с. 383-386.

Конеев Р.И. Наноминералогия золота. СПб., Delta, 2006, 220 с.

Кудрявцева А.И., Кудрявцев В.И. Проявление медистого и серебристого золота в благороднометалльном оруденении Южно-Тувинского гипербазитового комплекса // Состояние и освоение природных ресурсов Тувы и сопредельных регионов Центральной Азии. Геоэкология природной среды и общества / Ред. В.И. Лебедев. Кызыл, ТувИКОПР СО РАН, 2003, с. 45- 48.

Кужугет Р.В., Монгуш А.А., Мелекесцева И.Ю. Эволюция минералов ряда $\mathrm{Ag}-\mathrm{Au}-\mathrm{Hg}$ в рудах Алдан-Маадырской золоторудной зоны (Западная Тува) // Природные системы и экономика приграничных территорий Тувы и Монголии. (Материалы Молодежной научной конференции с международным участием (11-13 апреля 2012 г., Кызыл, Россия), Кызыл, ТувИКОПР СО РАН, 2012, с. 18-23.

Куличихина Р.Д., Губанов А.М. К исследованию природного соединения меди и золота из скарноворудного редкометалльного месторождения // Методические минералогические исследования. М., Наука, 1975, с. $62-64$.

Ложечкин М.П. Новые данные о химическом составе «медистого» золота // Докл. АН СССР, 1939, т. 24 , № 5, c. $454-457$.

Моисеенко В.Г. Геохимия и минералогия золота рудных районов Дальнего Востока. М., Наука, 1977, 304 c.

Мурзин В.В., Малюгин А.А. Новые данные о нестабильности природных твердых растворов системы $\mathrm{Ag}-\mathrm{Au}-\mathrm{Cu}$ в области температур менее $350{ }^{\circ} \mathrm{C} / /$ Докл. АН СССР, 1983, т. 269, № 3, с. $723-724$.

Мурзин В.В., Суставов С.Г. Твердофазное превращение в природном медистом золоте // Изв. АН СССР, Сер. геол., 1989, № 11, с. 94-104.

Мурзин В.В., Кудрявцев В.И., Берзон Р.О., Суставов С.Г. Медистое золото в зонах родингитизации // Геология рудных месторождений, 1987, т. 29, № 5, с. 96-99.

Мурзин В.В., Варламов Д.А., Шанина С.Н. Золотое оруденение в родингитах массивов альпинотипных гипербазитов // Литосфера, 2006, № 1, с. 113-134.

Мурзин В.В., Варламов Д.А., Шанина С.Н. Новые данные о золото-антигоритовой формации Урала // Докл. РАН, 2007, т. 417, № 6, с. 810-813.

Некрасов И.Я., Иванов В.В., Ленников А.М., Сапин В.И., Сафронов П.П., Октябрьский Р.А. Редкие природные многокомпонентные сплавы на основе золота и меди из платиновой россыпи Кондерского щелочно-ультраосновного массива (юго-восток Алданского щита, Россия) // Геология рудных месторождений, 2001, т. 43, № 5, с. 452-464.

Нестеренко Г.В., Кузнецова А.И., Лаврентьев Ю.Г. О природе самородного золота Синюхинского месторождения // Геология и геофизика, 1980 (10), с. 129-133.

Новгородова М.И. Самородные металлы в гидротермальных рудах. М., Наука, 1983, 287 с.

Новгородова М.И., Цепин А.И. О фазовом составе медистого золота // Докл. АН СССР, 1976, т. 227 , № 1 , с. $184-187$.

Новгородова М.И., Цепин А.И., Горшков А.И., Кудревич И.М., Вяльсов Л.Н. Новые данные по кристаллохимии и свойствам природных интерметаллических соединений системы медь-золото // Зап. ВMO, 1977, ч. 106, вып. 5, с. 540-552.

Пальянова Г.А. Физико-химические особенности поведения золота и серебра в процессах гидротермального рудообразования. Новосибирск, Изд-во СО РАН, 2008, 221 с.

Пальянова Г.А., Шваров Ю.В., Широносова Г.П., Лаптев Ю.В. Методические подходы к оценке пробности золота при термодинамическом моделировании гидротермальных систем // Геохимия, 2005, № 12, с. 1353 - 1357 .

Пальянова Г.А., Кох К.А., Сереткин Ю.В. Образование сульфидов золота и серебра в системе $\mathrm{Au}-\mathrm{Ag}-\mathrm{S} / /$ Геология и геофизика, 2011, т. 52 (4), с. 568-576.

Пальянова Г.А., Кох К.А., Сереткин Ю.В. Сульфидные и самородные формы золота и серебра в системе $\mathrm{Fe}-\mathrm{Au}-\mathrm{Ag}-\mathrm{S} / /$ Геология и геофизика, 2012, т. 53 (4), с. $450-460$. 
Петровская Н.В. Золотые самородки. М., Наука, 1993, 191 с.

Петровская Н.В., Новгородова М.И. Распад и упорядочение природных золото-серебряных твердых растворов // Упорядочение и распад твердых растворов в минералах. М., Наука, 1980, с. 177_184.

Покровский П.В., Мурзин В.В., Берзон Р.О., Юникова Б.А. Минералогия самородного золота месторождения Золотая Гора // Зап. ВМО, 1979, т. 108, с. 317-326.

Разин Л.В. Минералы - природные сплавы золота и меди в рудах медно-никелевых месторождений Норильского района // Тр. Минерал. музея АН СССР, 1975, вып. 24, с. 93-106.

Разин Л.В., Бегизов В.Д. Золото-серебряная минерализация Талнахского и Октябрьского месторождений норильского типа // Геология рудных месторождений, 1973, № 6, с. 32- 42.

Рамдор П. Рудные минералы и их срастания. М., Изд-во иностр. лит., 1962, 1132 с.

Самусиков В.П. Зависимость концентраций меди в самородном золоте от его пробности (на примере месторождений северо-востока СССР) // Докл. АН СССР, 1981, т. 260, № 5, с. 1238-1241.

Самусиков В.П. Закономерности концентрации изоморфно-примесных элементов в минералах при гидротермальном рудообразовании // Геология и геофизика, 2010, т. 51 (3), с. 338 - 352.

Синякова Е.Ф., Косяков В.И. Поведение примесей благородных металлов при фракционной кристаллизации $\mathrm{Cu}-\mathrm{Fe}-\mathrm{Ni}$-сульфидных расплавов, содержащих As и Co // Геология и геофизика, 2012, т. $53(10)$, с. $1374-1400$.

Спиридонов Э.М. Обзор минералогии золота в ведущих типах Аu минерализации // Золото Кольского полуострова и сопредельных регионов (Труды Всероссийской (с международным участием) научной конференции, посвященной 80-летию Кольского НЦ РАН. Апатиты, 26-29 сент. 2010 г.) / Ред. Ю.Л. Войтеховский. Апатиты, К \& M, 2010, с. 143-171.

Спиридонов Э.М., Плетнев П.А. Месторождение медистого золота Золотая Гора (о «золото-родингитовой» формации). М., Научный мир, 2002, 220 с.

Хисина Н.Р., Урусов В.С. Субсолидусные превращения твердых растворов породообразующих минералов. М., Наука, 1987, 206 с.

Чекрыжов И.Ю., Паничев А.М., Сафронов П.П., Голохваст К.С., Ведягин А.А., Бухтияров В.И. Геологические и биологические аспекты находки микрочастиц природного сплава $(\mathrm{Au}-\mathrm{Cu}-\mathrm{Ag})$ в кайнозойских цеолитизированных туфах Ванчинской впадины (Приморский край) // ДАН, 2011, т. 436, № 1, с. 103-105.

Чудненко К.В. Термодинамическое моделирование в геохимии: теория, алгоритмы, программное обеспечение, приложения. Новосибирск, Изд-во «Гео», 2010, 287 с.

Andersen J.C.O., Rasmussen H., Nielsen T.F.D., Ronsbo J.G. The Triple Group and the Platinova Gold and Palladium Reefs in the Skaergaard Intrusion: stratigraphic and petrographic relations // Econ. Geol., 1998, v. 93, p. $488-509$.

Arif J., Baker T. Gold paragenesis and chemistry at Batu Hijau, Indonesia: implications for gold-rich porphyry copper deposits // Miner. Deposita, 2004, v. 39, p. 523-535.

Bonev I.K., Kerestedjian T., Atanassova R., Andrew C.J. Morphogenesis and composition of native gold in the Chelopech volcanic-hosted Au-Cu epithermal deposit, Srednogorie zone, Bulgaria // Miner. Deposita, 2002, v. 37, № 6-7, p. 614-629.

Chapman R.J., Leake R.C., Bond D.P.G., Stedra V., Fairgrieve B. Chemical and mineralogical signatures of gold formed in oxidizing chloride hydrothermal systems and their significance within populations of placer gold grains collected during reconnaissance // Econ. Geol., 2009, v. 104, p. 563-585.

Dinsdale A.T., Watson A., Kroupa A., Zemanowa A., Vrestal J., Vidal J. COST 531. V. 3.0 Thermodynamic Database, 2008. http://www.univie.ac.at/cost531/

He X.C., Wang H., Liu H.S., Jin Z.P. Thermodynamic description of the $\mathrm{Cu}-\mathrm{Ag}-\mathrm{Zr}$ system // Computer Coupling of Phase Diagrams and Thermochemistry, 2006, v. 30, p. 367-374.

Hillert M. Phase equilibria, phase diagrams and phase transformations. Cambridge, Cambridge University Press, 2008, 510 p.

Hultgren R., Orr R.L., Anderson P.D., Kelley K.K. Selected values of thermodynamic properties of metals and alloys. New York, Wiley, 1963, 963 p.

Knight J., Leitch C.H.B. Phase relations in the system $\mathrm{Au}-\mathrm{Cu}-\mathrm{Ag}$ at low temperatures, based on natural assemblages // Canad. Miner., 2001, v. 39, p. 889-905.

Knipe S.W., Fleet M.E. Gold-copper alloy minerals from the Kerr Mine, Ontario // Canad. Miner., 1997, v. 35 , p. $573-586$.

McDonald A.S., Sistare G.H. The metallurgy of some carat gold jewellery alloys // Gold. Bull., 1978, № 3, p. 66-73. 
Muggianu Y.-M., Gambino M., Bros J.-P. Enthalpies of formation of liquid alloys bismuth-gallium-tin at $723 \mathrm{~K}$. Choice of an analytical representation of integral and partial excess functions of mixing // J. Chimie Physique, 1975, v. 72, p. $83-88$.

Norman H., Warren B. X-ray measurements of short range order in Ag-Au // J. Appl. Phys., 1951, v. 22, № 4, p. 483-486.

Oen I.S., Kieft C. Nickeline with pyrrhotite and cubanite exsolutions, Ni-Co rich loellingite and an Au$\mathrm{Cu}$ alloy in Cr-Ni ores from Beni-Bousera, Morocco // Neues Jahrb. Miner. Monatsh., 1974, p. 1-8.

Okamoto H., Chakrabarti D.J., Laughlin D.E., Massalski T.B. Bulletin of Alloy Phase Diagrams, 1987, v. 8, p. $454-474$.

Predel B. Au-Cu (gold-copper) // Landolt-Bornstein, Group IV: physical chemistry - phase equilibria, crystallographic and thermodynamic data of binary alloys, v. 5. Light metal structural alloys / Ed. O. Madelung. Berlin, Springer-Verlag, 2005, 810 p.

Redlich O., Kister A.T. Algebraic representation of thermodynamic properties and the classification of solutions // Ind. Eng. Chem., 1948, v. 40, p. 248-345.

Robie R.A., Hemingway B.S. Thermodynamic properties of minerals and related substances at $298.15 \mathrm{~K}$ and 1 bar $\left(10^{5}\right.$ Pascals $)$ pressure and at higher temperatures // U. S. Geol. Survey Bull., v. 2131. Washington, 1995, $461 \mathrm{p}$.

Shock E.L., Sassani D.C., Willis M., Sverjensky D.A. Inorganic species in geologic fluids: correlations among standard molal thermodynamic properties of aqueous ions and hydroxide complexes // Geochim. Cosmochim. Acta, 1997, v. 61, p. 907-950.

Sundman B., Fries S., Oates W. A thermodynamic assessment of the $\mathrm{Au}-\mathrm{Cu}$ system // Calphad, 1998, v. 22 , p. $335-354$.

Sverjensky D.A., Shock E.L., Helgeson H.C. Prediction of thermodynamic properties of aqueous metal complexes to $1000^{\circ} \mathrm{C}$ and $5 \mathrm{~kb} / /$ Geochim. Cosmochim. Acta, 1997, v. 61, p. 1359-1412.

White J.L., Orr R.L., Hultgren R. Thermodynamic properties of silver-gold alloys // Acta Metallurgica, 1957, v. 5, p. $747-760$. 